\title{
Angiostatin and Anti-angiogenic Therapy in Human Disease
}

\author{
Miriam L. Wahl, Tammy L. Moser, and Salvatore V. Pizzo \\ Department of Pathology, Duke University Medical Center, Durham, North Carolina 27710
}

\begin{abstract}
Many diseases have abnormal quality and/or quantity of vascularization as a characteristic feature. Cancer cells elicit the growth of new capillaries during neovascularization in a process termed angiogenesis. In diabetics, pathologic angiogenesis in various tissues is a clinical feature of many common complications. Therefore, the diabetic cancer patient warrants special consideration and extra care in the design of anti-angiogenic treatments without adverse side effects. Some treatment regimens that look promising in vitro, in animal models, or in early clinical trials may be contra-indicated for diabetics. This chapter will review the common complications of diabetes, with emphasis on the angiogenic pathology. Recent research related to the mechanism of action and basis for specificity of the anti-angiogenic peptide, angiostatin, will be the focus. The aim is to shed light on areas in which more research is needed with respect to angiostatin and other anti-angiogenic agents and the microenvironmental conditions that affect their activities, in order to develop improved therapeutic strategies for diabetic cancer patients.
\end{abstract}

\section{Introduction}

Normal tissue function relies on an adequate supply of nutrients and oxygen from pre-existing blood vessels. It is well established that tumor growth depends on development of a new vascular supply, a process known as angiogenesis (Folkman, 1971). The discovery of factors that mediate this process has significantly increased our understanding of many normal and pathological circumstances. For example, angiogenesis is desirable in wound healing and recovery from cardiac ischemia but undesirable in the pathogenesis of psoriasis (Oates, 2002) or when metastastic tumor tissue develops a blood supply, allowing it to grow and spread (Weidner et al., 1991,1993; Macchiarini et al., 1992). The quest has been to isolate naturally occurring agents or develop new ones that aid in the regulation of this process. Judah Folkman initially developed the hypothesis that naturally occurring agents existed that inhibited angiogenesis. The first two, discovered in his laboratory, were angiostatin (O'Reilly et al., 1994a) and endostatin (O'Reilly et al., 1997).

As tumors grow in size, they become hypoxic and acidotic and elaborate several growth factors to stimulate local blood vessels to sprout branches. 
Endothelial cells then begin proliferating towards the tumor and form tubular structures that become blood vessel branches. These new blood vessel branches differ from normal blood vessels. Some agents can target them while not harming intact, mature vasculature elsewhere in the body. For example, newly formed blood vessels are "leaky" or exceptionally permeable (Dvorak et al., 1988). They also are tortuous, with blind ends and incomplete drainage or backflow (Secomb et al., 1993; Kimura et al., 1996) and therefore contain a mixture of arterial and venous blood (Kallinowski et al., 1988; Vaupel, 1997; Vaupel et al., 1989,1998). This makes them poor at removing catabolites, including carbon dioxide $\left(\mathrm{CO}_{2}\right)$ (Boyer and Tannock, 1992).

Angiostatin is endogenously produced in the tumor stroma. Therefore, circulating levels can control metastatic cell proliferation until a primary tumor is removed. Before the discovery of angiostatin, it was believed that when cancer recurred after surgical removal of a primary tumor, it was because the surgeon had left some tumor cells behind. It is now generally accepted that micrometastases already have seeded elsewhere in the body but were inhibited from proliferating by endogenous production of angiostatin or other inhibitors from the primary tumor. These micrometastases then came under permissive growth conditions when the primary tumor was removed. The discovery of angiostatin elicited great excitement because it seemed likely that exogenous administration after primary tumor removal could prevent metastatic growth. However, one problem is the short half-life of this peptide, leading to a need for continuous administration. Identifying receptors for these molecules was deemed a high priority, so that alternate molecules could be developed that have the same targets and are more stable, more effective, and easier to manufacture and administer.

Angiostatin is found naturally in significant amounts in the circulation of patients with primary tumors (Canfield et al., 1986; Cao et al., 2000; OSI Pharmaceuticals et al., 2001). When a primary tumor is removed, metastases may experience lower circulating levels of endogenous inhibitors. Local blood vessels respond to the malignant cells' elaboration of vascular endothelial growth factor (VEGF) and fibroblast growth factor (FGF). Local blood vessels then respond by sprouting branches to feed the metastases. At this time, small micrometastases may grow beyond the 2-mm size, which is functionally dormant, and become a threat to the patient when rapid growth causes local damage. Angiostatin can maintain metastases in a dormant state in laboratory animals when administered exogenously (O'Reilly et al., 1994a,b,1997). Research on the mechanism of action of angiostatin delineates some parameters affecting its activity that will require evaluation, in order to design treatments that yield the most-effective combinations of agents. More-complicated issues are whether these treatments are applicable in patients having a variety of vascular pathologies. Diabetic patients have other body compartments that feature abnormal vascularization. Understanding how these anti-angiogenic agents work and the conditions in the 
various compartments will enable predictions about possible side effects, permitting further drug development. Many agents are in clinical trials (Table I), with alarmingly little known about their mechanisms of action and potential side effects.

\section{Stages of Tumor Angiogenesis}

Angiogenesis begins when a fibrin clot forms on the adventitial surface of an existing blood vessel (Muthukkaruppan and Auerback, 1970; van Hinsbergh et al., 2001), followed by sprouting of new capillaries. The initial phase begins with increased vascular permeability and local degradation of the vessel wall (i.e., extracellular matrix (ECM) or basement membrane). The endothelial cells enter the tumor stroma, migrate toward a stimulus such as VEGF or FGF, and proliferate behind the leading edge. At this time, the cells may be most vulnerable to agents that interfere with their proliferation, since they lack protection from other cell types (Egginton et al., 2000). The next step in vessel formation is recruitment of pericytes, followed by smooth muscle cells.

\section{On/Off Switches for Angiogenesis: a Delicate Balance}

Angiostatin is a fragment of a larger protein, plasminogen, with an activity distinct from the parent protein. It may be cleaved from the original precursor protein by enzymes under various conditions; normally, in cases where a pro-angiogenic stimulus first has promoted blood vessel development (such as during wound healing), which must then be inhibited when the desired level of vascularity has been achieved. Angiostatin has a short half-life of about 15 minutes (Gonzalez-Gronow et al., 1990; DeMoraes et al., 2001; Fortier et al., 2001). Consistent with these results, exogenous administration of angiostatin at doses ranging from $15-300 \mathrm{mg} / \mathrm{m}^{2} /$ day showed rapid clearance of this protein and no side effects in a phase I clinical trial performed at Thomas Jefferson University (DeMoraes et al., 2001; Fortier et al., 2001). Based on animal studies, however, if administered continuously in addition to endostatin, metastasis may be discouraged from growth for prolonged lengths of time (Yokoyama et al., 2000). Combination therapies with two new agents are necessarily slow to be tested in humans. Each compound has to be tested individually first in patients and, if they are only effective together, the potential efficacy may not be discernable in early trials. Recent combinations that have been studied in animal models include angiostatin with chemotherapy (te Velde et al., 2002) and angiostatin with radiation (Mauceri et al., 1998). Basic research is needed to understand mechanisms and predict which combinations will be most effective, so that trials can be done in the correct context, the right tumor types, and thus in patients that will benefit the most. Furthermore, deleterious side effects should 
TABLE I

Antiangiogenic Agents

\begin{tabular}{|c|c|c|c|}
\hline Angiogenesis inhibitors & Target & $\begin{array}{l}\text { Trial } \\
\text { phase }\end{array}$ & References \\
\hline $\begin{array}{l}\text { ABX EGF, Cl-1033, PKI-166, EGF vaccine, } \\
\text { EKB-569, GW2016, ICR-62, EMD 55900, } \\
\text { CP358, PD153035, AG1478 }\end{array}$ & EGFR & I & Bier et al., 1995; Schober et al., 1995 \\
\hline $\begin{array}{l}\text { IMC-C225 (Erbitux), ZD1839 (Iressa), } \\
\text { OSI-774 }\end{array}$ & EGFR & II/III & $\begin{array}{l}\text { Robert et al., 2001; Albanell et al., 2002; } \\
\text { Baselga et al., 2002; Herbst et al., 2002c; } \\
\text { Ranson et al., 2002 }\end{array}$ \\
\hline Erlotinib (tarceva) & EGFR & III & OSI Pharmaceuticals et al., 2001 \\
\hline Angiostatin & $\begin{array}{l}\text { ATP synthase on endothelial cells; } \\
\text { intracellular pH regulation; angiomotin; } \\
\text { annexin II }\end{array}$ & I & $\begin{array}{l}\text { Moser et al., 1999, 2001; Troyanovsky et al., } \\
\text { 2001; Wahl et al., 2001, 2002a; Wahl and } \\
\text { Grant, } 2002\end{array}$ \\
\hline Arrestin, endostatin & $\alpha_{1} \beta_{1}$ on endothelial cells & No, I/II & $\begin{array}{l}\text { Colorado et al., 2000; Mundhenke } \text { et al., 2001; } \\
\text { Eder } \text { et al., 2002; Herbst } \text { et al., 2002a,b; } \\
\text { Sudhakar } \text { et al., 2003; Thomas } \text { et al., } 2003\end{array}$ \\
\hline $\begin{array}{l}\text { BAY } 12-9566 \text { \& w/fluorouracil or } \\
\text { doxorubicin }\end{array}$ & $\begin{array}{l}\text { Metalloproteinase inhibitor-2, }-3,-9 \text { (multiple } \\
\text { target) }\end{array}$ & I & Heath et al., 2001 \\
\hline Bevacizumab (avastin) & VEGF antagonist & II, III & Chen et al., 2001 \\
\hline Carboxyamidotrizole, and w/paclitaxel & Inhibits endothelial cells calcium influx & I & Kohn et al., 2001 \\
\hline Canstatin, EMD121974, S-24, vitaxin & $\alpha_{v} \beta_{3}$ integrin antagonist & $\mathrm{I}, \mathrm{I}, \mathrm{I}, \mathrm{I} / \mathrm{II}$ & $\begin{array}{l}\text { Gutheil et al., 2000; Eder et al., 2002; Herbst et } \\
\text { al., 2002b; Thomas et al., } 2003\end{array}$ \\
\hline Dimethylxanthenone acetic acid & Unclear, induces TNF- $\alpha$ and nitric oxide I & No & Galbraith et al., 2002 \\
\hline IM862 & Activates NK cells & I & Tulpule et al., 2000 \\
\hline Interleukin-12, interleukin-2 & Induces CD8+ T-cell receptor $\& \alpha \beta+\mathrm{T}$ cells & I & Brivio et al., 2002 \\
\hline NM-3 & VEGF inhibitor & I & Reimer et al., 2002 \\
\hline HuMV833 PTK787, ZK22584 & VEGF receptor antagonists & I & Jayson et al., 2002; Turetschek et al., 2002 \\
\hline
\end{tabular}


RhuMab, Angiozyme (ribozyme)

IMC-1C11

Neovastat, Marimastat, Prinomastat, BMS275291, COL-3, MM1270

SU101, SU6668, SU11248

SU5416, with Paclitaxel, w/Gemcitabine \& Cisplatin, and w/Irinotecan \& Cisplatin

and w/radiation

Razoxane

Squalamine lactate

Tecogalan

Temozolomide \& PEG interferon $\alpha 2 \mathrm{~b}$

Tetrathiomolybdate

TNP-470

Thalidomide, CC-5013 (immunomodulatory derivative of thalidomide), and with

taxotere

Tumstatin

2-methoxyestradiol

VEGF trap
VEGF receptor antagonists

VEGFR-2 antagonists

Matrix metalloproteinase inhibitors

PDGFR, VEGFR, bFGF (multiple targets) endothelial cells/pericytes

VEGFR-2 antagonist

Topoisomerase II inhibitor

Sodium/proton antiporter isoform III

Inhibits bFGF binding

Unknown

Anticopper agent

Inhibits endothelial cell proliferation

Unknown

$\alpha_{\mathrm{v}} \beta_{3}$ integrin antagonist

Hypoxia inducible factor (HIF1 $\alpha)$

Decoy soluble VEGFR
I/II/III

Posey et al., 2003

et al., 2001; Rudek et al., 2001; Batist $e t$ al., 2002; Shepherd et al., 2002; Reber et al. 2003

Eckhardt et al., 1999; Whatmore et al., 2002;

Bergers et al., 2003

Stopeck et al., 2002

Braybrooke et al., 2000

Akhter et al., 1999; Bhargava et al., 2001

Eckhardt et al., 1996

Agarwala and Kirkwood, 2003

I,II Brewer et al., 2000; Redman et al., 2003

I Logothetis et al., 2001

I Baidas et al., 2000; Figg et al., 2001; Short et al., 2001; Daliani et al., 2002; Escudier et al., 2002; Gutheil and Finucane, 2002

No Sudhakar et al., 2003

I Lakhani et al., 2003

I Herbst et al., 2002c

[Abbreviations: EGFR, epidermal growth factor receptor; ATP, adenosine triphosphate; VEGF, vascular endothelial growth factor; TNF, tumo necrosis factor; NK, natural killer; VEGFR, VEGF receptor; PDGFR, platelet-derived growth factor receptor; bFGF, bovine fibroblast growth factor.] 
be predictable and avoidable if comparison between compartmental microenvironment and tumor microenvironment are made and the effects of these determinants on the drug activity are understood.

\section{Mechanisms of Action of Angiostatin}

One major theme that has emerged from research done thus far on antiangiogenic compounds is that the extent of cell attachment to a matrix and the nature of the matrix are critical determinants of the compound's activity. This is a complex issue because tumor stroma is comprised of a variety of proteins, often in abnormal relative concentrations. Extensive literature indicates that, in addition to tumor cell modulation of stroma composition, stromal components impact tumor cells. This two-directional signaling is part of the malignant phenotype and often is regulated at the post-transcriptional level. This pioneering work, recently reviewed by Roskelley and Bissell (2002), has delineated the importance of tumor stroma in tumor cell behavior. Recent work in the field of angiogenesis has shown that many of the same microenvironmental factors are critical to the endothelial cell response to the tumor microenvironment and can determine the phenotype of these cells and the outcome of exposure to various stimuli (e.g., administration of exogenous angiostatin) (Wahl and Grant, 2002).

Angiostatin is an internal fragment of plasminogen and may contain either the first three (K1-3) or four (K1-4) kringle domains. A similar activity has been reported for kringle 5 (K-5) of plasminogen (Liu et al., 2000; Gonzalez-Gronow et al., 2003). Three receptors on endothelial cells have been reported for angiostatin to date. Adenosine triphosphate (ATP) synthase was the first receptor identified by Moser and colleagues (1999). The presence of this typically mitochondrial enzyme on the endothelial cell surface was somewhat surprising. Binding of angiostatin to surface-associated ATP synthase since has been confirmed by other research groups (Wahl and Grant, 2002; Arakaki et al., 2003). Additional reports have confirmed the unexpected finding that many of the enzymes and components of the mitochondrial electron transport chain and ATP synthesis generating mechanisms are located on the plasma membrane of endothelial cells (Yegutikin et al., 2002; Arakaki et al., 2003). Two other potential target receptors of angiostatin that have been reported are angiomotin (Troyanovsky et al., 2001) and integrin $\alpha_{\mathrm{v}} \beta_{3}$ (Tarui et al., 2001). The distribution of these receptors on the surface of endothelial cells may be located at sites so proximal to one another that angiostatin may be able to interact with more than one simultaneously. Alternatively, multiple targets could be implicated in binding to the different kringles of angiostatin as a function of receptor and peptide presentation.

Parameters affecting angiostatin's interaction with the ATP synthase receptor have not been completely elucidated but recent work indicates that the 
synthase may be situated in a caveolar compartment (Moser et al., 2001) and generates ATP on the cell surface (T.L. Moser, D.J. Cheek, J.A. Roy, T.A. Ashley, M.D. Goodman, A.E. Paradis, B. Li, D.J. Kenan, and S.V. Pizzo, unpublished results). It has been reported that one of angiostatin's receptors is proximal to focal adhesion kinase (FAK) and that binding catalyzes FAK phosphorylation in the absence of integrin clustering that usually is triggered by cell attachment to substrate (Claesson-Welsh et al., 1998). This implies that FAK phosphorylation occurs under aberrant circumstances (i.e., when endothelial cells are not tightly attached to their normal substratum). In the usual scenario, attachment to a substrate such as fibronectin causes integrins to form tetramers. FAK is phosphorylated and organizes, allowing cytoskeletal elements to form structurally organized arrays to carry out cell spreading (Figures 1 and 2). In the tumor microenvironment, several parameters differ. Matrix composition includes collagen, laminin, and many other proteins (Canfield et al., 1986; Baatout and Cheta, 1996; Grant and Kleinman, 1997; Aoudjit and Vuori, 2001). The pH and the oxygen levels are low and the degree of attachment is compromised because cells are rapidly dividing and moving into areas requiring a blood supply. This means that different integrin isoforms may be activated to differing extents

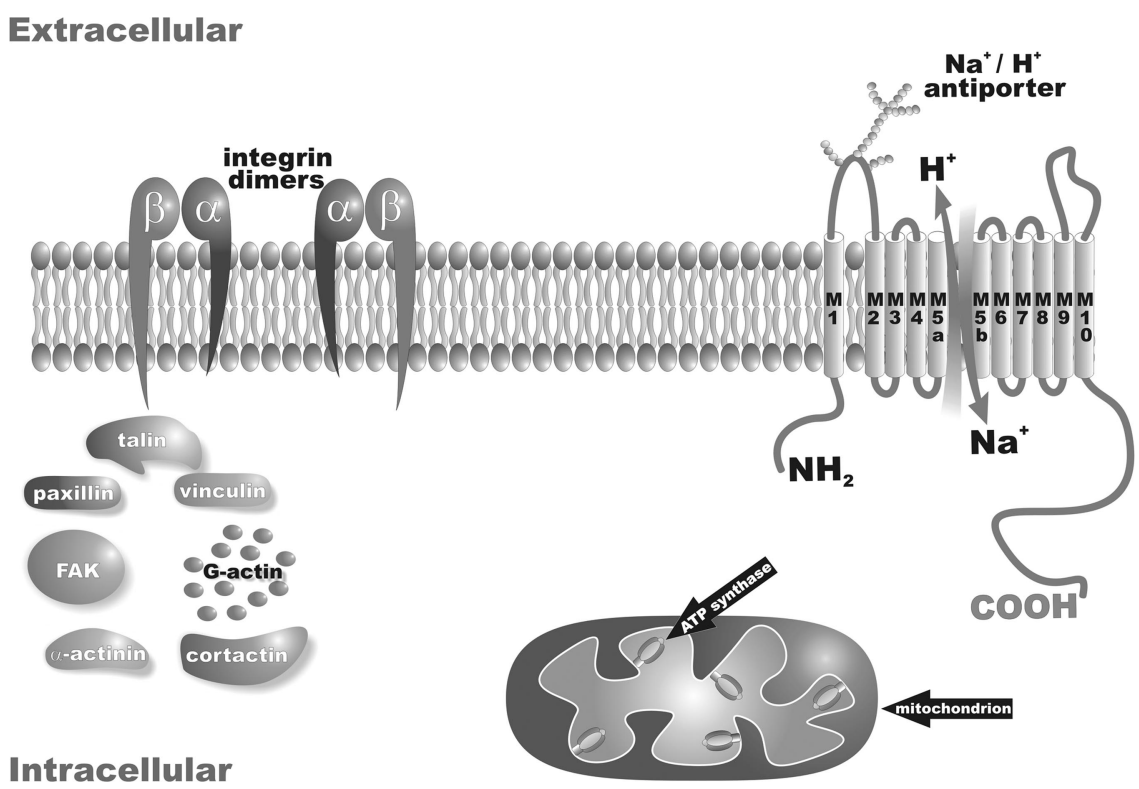

FIG. 1. Endothelial cell membrane in an unattached cell at normal $\mathrm{pH}(\approx 7.3)$. The integrin subunit are in $\alpha \beta$ dimers, the sodium proton antiporter (NHE) is minimally active, focal adhesion kinase (FAK) is unphosphorylated, cytoskeletal elements are unassembled, and adenosine triphosphate (ATP) synthase is active primarily within the mitochondria. 


\section{Extracellular}

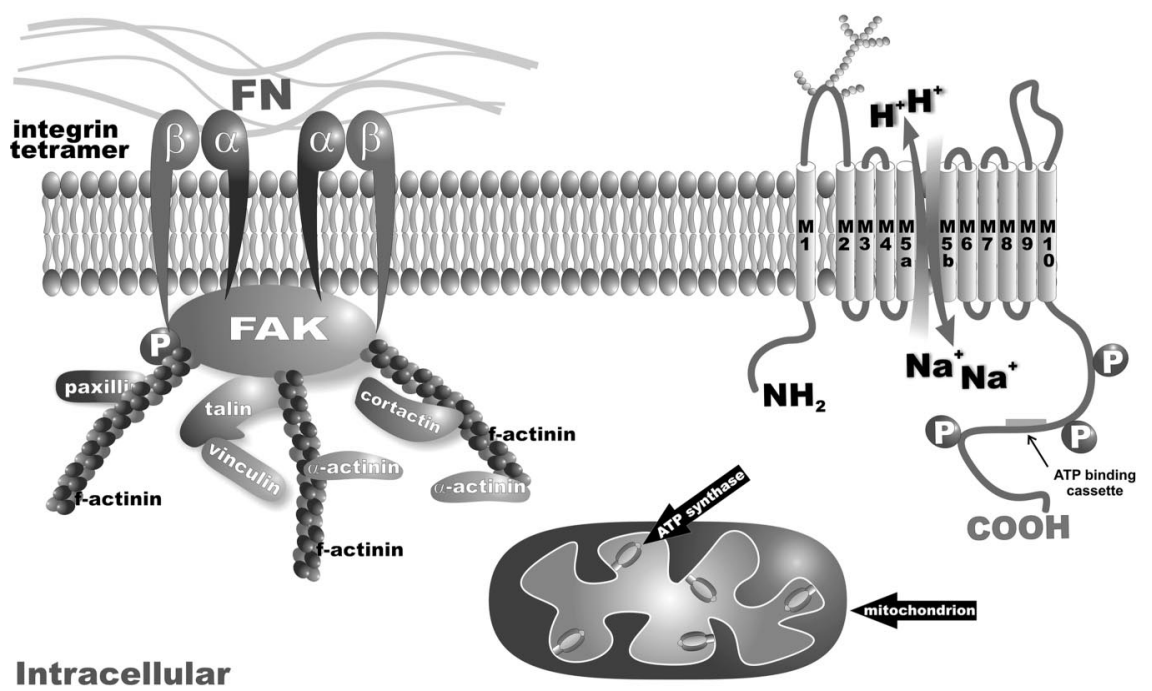

FIG. 2. Endothelial cell attached to fibronectin at normal $\mathrm{pH}(\approx 7.3)$. Integrins are clustered into tetramers in response to attachment to fibronectin, FAK is phosphorylated, NHE is more active, cytoskeletal elements are assembled to promote cell attachment and spreading, and ATP synthase remains in mitochondria.

(Schwartz et al., 1991b; Agius et al., 1996; Coopman et al., 1996; ErdreichEpstein et al., 2000). Thus, the distribution of other molecules on the cell surface and their activities will be affected. When extracellular $\mathrm{pH}$ is low, typically the sodium/proton antiporter, isoform 1 (NHE-1), is activated to maintain intracellular $\mathrm{pH}$ in the viable range. This occurs as a function of attachment, phosphorylation, ATP binding, and the presence of growth factors in fibroblasts, where it has been studied in the most detail (Schwartz et al., 1991a; McSwine et al., 1994). It has been reported that migrating cells have NHE-1 clustering at the leading edge of lamellopodia in work done using fibroblasts (Grinstein et al., 1993) and melanoma cells (Akasaka et al., 1995) and that they co-localize in partially attached and moving cells with FAK (Schwartz et al., 1991a).

We recently demonstrated that when coupled with extracellular acidification, angiostatin caused a precipitous decline in cytosolic intracellular $\mathrm{pH}$ (Wahl et al., 2001,2002a; Wahl and Grant, 2002). Low extracellular pH could affect receptor levels, receptor distribution, angiostatin binding, and angiostatin conformation. ATP synthase distribution on the endothelial cell surface was reported to be more focal at low pH (Wahl and Grant, 2002). Receptor binding interactions with angiostatin as a function of extracellular $\mathrm{pH}$ currently are being studied in our laboratories. At normal extracellular pH, both ATP synthase and NHE-1 would 
be less active, whether or not cells are attached. However, in the tumor microenvironment (Figures 3 and 4), there is less attachment to a variety of substrate proteins, a lack of integrin clustering, and aberrant FAK phosphorylation. Because of the low extracellular tumor $\mathrm{pH}, \mathrm{NHE}-1$ is activated and ATP synthase is activated and organized focally (Wahl and Grant, 2002). When angiostatin enters this scenario, it could bind to ATP synthase, which could, in turn, disrupt FAK, ATP synthesis, and the function of NHE-1. A model for how angiostatin binding affects endothelial cells in a tumor microenvironment based on recent research, the literature, and conjecture - is shown in Figure 4.

\section{Other Anti-angiogenic Agents}

Other anti-angiogenic agents have been discovered or developed. In some cases, the receptors have been identified (Table I). However, little is known about how their signals are transduced, the basis for their selectivity, or their degree of

\section{Extracellular}

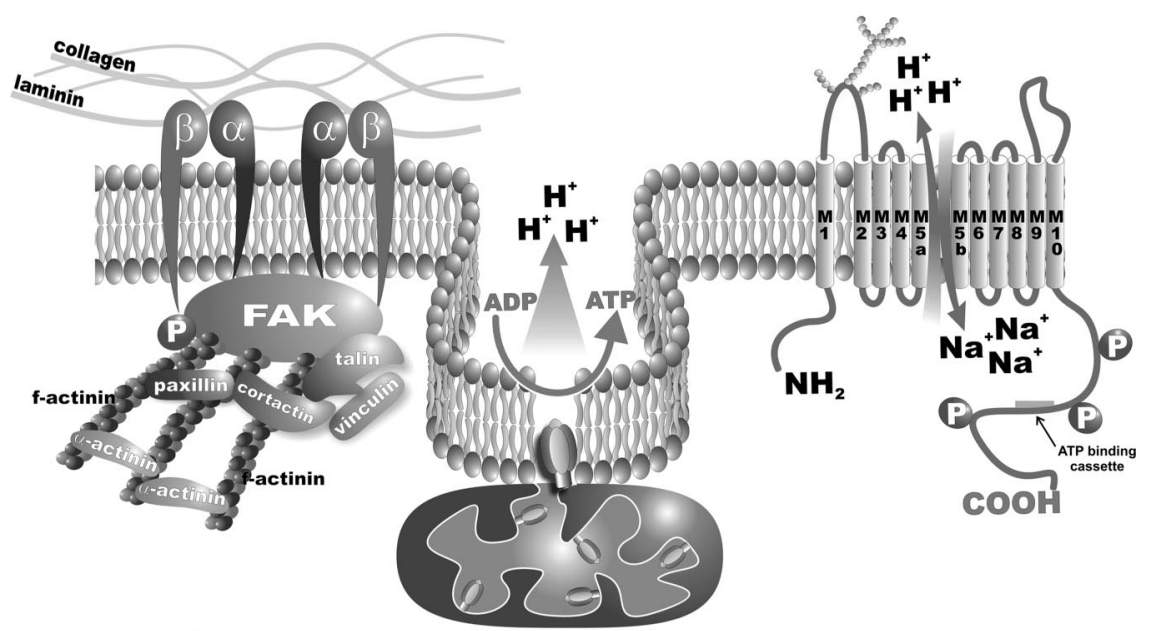

\section{Intracellular}

FIG. 3. Endothelial cell in a tumor microenvironment with a low and variable pH. Cells are partially attached to various matrix proteins, including collagen and laminin, different integrin isoforms cluster in tetramers, and ATP synthase appears in caveolae situated near FAK. This ATP synthase now generates ATP on the plasma membrane. FAK is phosphorylated. Extracellular pH is lower (6.7 on average) and migration of endothelial cells is required; therefore, NHE is very active, highly phosphorylated, and has ATP bound on the cytoplasmic tail. NHE molecules congregate at the leading edge of lamellopodia to generate a sodium gradient to bring about cell movement. Signals are transduced to cytoskeleton, which catalyzes a rearrangement of cytoskeletal elements. Cells then proliferate and can differentiate into tubular structures. 


\section{Extracellular}

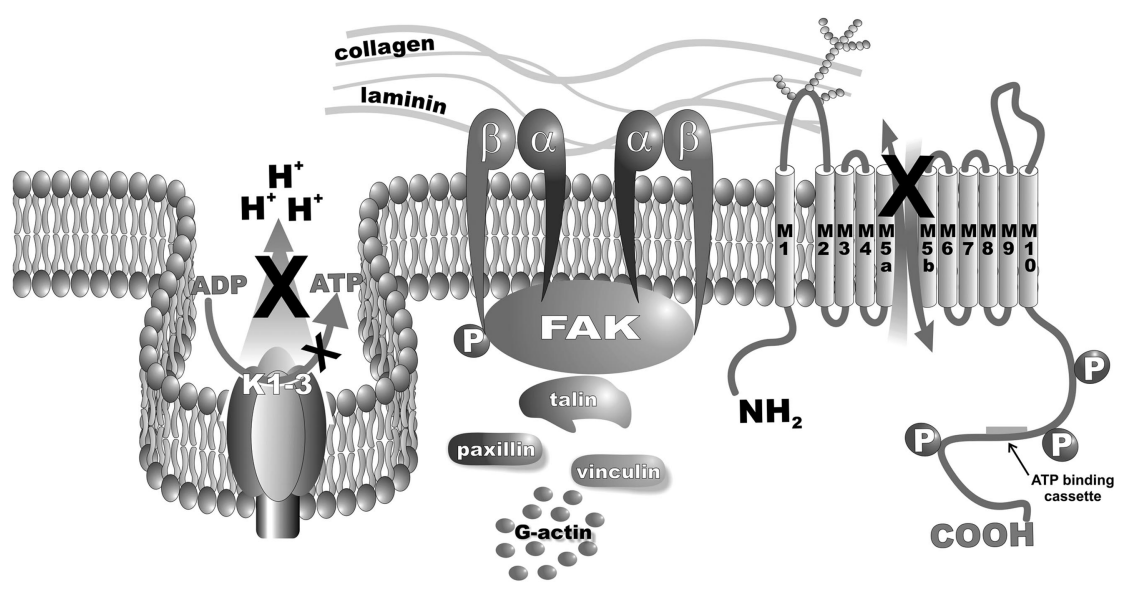

\section{Intracellular}

FIG. 4. Proliferating endothelial cells in the tumor microenvironment in the presence of angiostatin. Angiostatin binds to the catalytic subunit of ATP synthase. ATP synthesis ceases and inhibits the synthesis of extracellular ATP. Rapid proliferation loosens attachment of the cells, integrin tetramers dissociate into dimers, and NHE molecules disaggregate. FAK is phosphorylated (as in Figure 2) but under conditions where attachment is not being maintained. NHE is inhibited by lack of attachment, dephosphorylations, and loss of ATP. Intracellular pH decreases below 6.5 and metabolism ceases. The cell has received conflicting signals, which trigger a signal transduction cascade ending in apoptosis.

selectivity. Features of the tumor microenvironment that have been shown to be critical for demonstrating angiostatin activity are delineated below, emphasizing parameters that should be evaluated for other anti-angiogenic agents that may be useful to determine in which clinical scenario(s) each is likely to be most effective.

Some characteristic features of the tumor microenvironment may be shared by other improperly vascularized areas. This means that anti-angiogenic therapies could cause complications for cancer patients with diabetes mellitus. Drugs for treating tumors may have undesirable side effects in other tissues in diabetics to a greater extent than in nondiabetics. Some of these features have been described but have not been characterized fully in terms of application of anti-angiogenic agents. Differences between vasculature arising in different locations, in endothelial cells from the various tumor types, and in different ECM microenvironments are also areas where further basic research is warranted. 
Some major parameters that need to be examined for each anti-angiogenic agent under consideration for clinical use are described in Section VI.

\section{Features of the Tumor Microenvironment: Potential Mediators of the Response of Tumor Stromal Endothelial Cells to Anti-angiogenic Drugs}

\section{A. VEGF \& FGF}

VEGF and FGF are two growth factors secreted by metastatic or primary tumor cells to encourage new vessel branch development. These growth factors are used as markers for vessel growth. In the first phase I clinical trial of angiostatin at Thomas Jefferson University, the protocol was designed to administer daily doses of intravenous (IV) angiostatin for 2-week intervals, separated by 1-week interruptions. Both VEGF and FGF rebounded rapidly in the circulation just 1 day after daily dosing stopped after each dosing interval (DeMoraes et al., 2001). This made it evident that daily dosing without interruption would be necessary to maintain the effects of angiostatin. It indicated that agents with a slower clearance time would probably be more practical clinically. Table I lists some anti-angiogenic agents currently in clinical trial. If these are expressed in excess and/or at inappropriate times, hypervascularization could occur.

\section{B. ENDOGENOUS INHIBITORS}

Other endogenous inhibitors of angiogenesis have been reported, including angiogenin (Fett et al., 1985), endostatin (O'Reilly et al., 1997), thrombospondin-1 (Nicosia and Tuszynski, 1994), interferons (Dinney et al., 1998), platelet factor-4 (Nicosia et al., 1994), and $16 \mathrm{kDa}$ prolactin (Hanahan and Folkman, 1996). Numerous other inhibitors, both naturally occurring and synthetic, are listed in Table I. Their relative abundance can play a role in the overall picture in various body compartments. Angiostatin has proven to be one of the most potent. In vitro, angiostatin is relatively specific for tumor endothelial cells and inhibits their proliferation (Moser et al., 1999), migration (Moser et al., 1999), tube formation (Moser et al., 1999; Wahl et al., 2002a), vessel network formation in the embryonic body model (Eriksson et al., 2003), and formation of sprouts from mouse aortic rings (Hajitou et al., 2002). Exceptions to this specificity include a published study on smooth muscle cells (Walter and Sane, 1999) and one on neutrophils (Benelli et al., 2002). In vivo, however, angiostatin inhibits primary tumor metastasis in mice (O'Reilly et al., 1994b), vascular proliferation in the chick chorioallantoic membrane (CAM) assay (Gately et al., 1996), and neovascularization in the corneal pocket assay (White et al., 2003).

Angiostatin is found in normal human plasma at a concentration of $\approx 6-12$ $\mathrm{nM}$ (Soff et al., 1999). The concentration of angiostatin in the urine of cancer 
patients is significantly higher than in other patients (Cao et al., 2000). Elevated levels of angiostatin have been observed in the ascites fluid from ovarian cancer patients as well (Yokoyama et al., 2000). More recently, angiostatin was found to be elevated during impaired production of nitric oxide in coronary angiogenesis (Matsunaga et al., 2002) and in the bronchoalveolar lavage fluids from patients with acute respiratory distress syndrome (ARDS) (Lucas et al., 1998). These findings may indicate that angiostatin functions not only as a tumorspecific inhibitor but also as a regulator of angiogenesis in other scenarios.

\section{PERICYTES \& SMOOTH MUSCLE CELLS}

Pericytes and smooth muscle cells are recruited to surround the endothelial cell tubes in developing blood vessels, so reduced numbers of them could affect the levels of various stimulators and inhibitors to which endothelial cells are exposed. Platelet-derived growth factor (PDGF) plays a major role in pericyte recruitment. When vessels initially form, their vulnerability may be maximal in part because these other cell types are not there to provide a mechanical barrier. A recent study indicates that retinal capillary coverage by pericytes was crucial for survival of endothelial cells in retina subjected to hypoxic conditions, particularly under the stress conditions of diabetes (Hammes et al., 2002). Pericytes also secrete similar growth factors and thus modulate the ECM (Allt and Lawrenson, 2001). Smooth muscle cell proliferation also is inhibited by angiostatin (Walter and Sane, 1999).

\section{INTRACELLULAR \& EXTRACELLULAR $\mathrm{pH}$}

Both intracellular and extracellular $\mathrm{pH}$ affect angiostatin activity. The average extracellular $\mathrm{pH}(5.6-7.6)$ in tumors is lower and more variable than in normal tissue (7.2-7.6), yet tumors have a normal average intracellular $\mathrm{pH}$ (Yamagata and Tannock, 1996). It has been reported that angiostatin profoundly affects intracellular $\mathrm{pH}$ in endothelial cells (Wahl and Grant, 2002; Wahl et al., 2002a). This effect is manifested only at low extracellular $\mathrm{pH}$. This implicates $\mathrm{pH}$-regulating transporters that are activated at low extracellular $\mathrm{pH}$ as a potential class of targets for anti-angiogenic agents in areas of tumors where extracellular $\mathrm{pH}$ is low. These potentially include NHE and the $\mathrm{H}^{+}$-linked monocarboxylate transporter (MCT).

\section{E. ATP SYNTHASE RECEPTOR LEVELS}

Modulation of angiostatin's receptor levels may be a determinant of angiostatin activity. Research has shown that ATP synthase distribution can be altered as a function of ECM composition and extracellular $\mathrm{pH}$. When cells are allowed to attach to fibronectin, histochemical assays using a primary antibody 
directed against the $\beta$ subunit of ATP synthase showed no detectable enzyme on the cell surface. However, when cells were plated on Matrigel to simulate the tumor stroma, the enzyme was revealed on the cell surface (Wahl and Grant, 2002). When cells at normal and low extracellular pH were compared, the distribution at low $\mathrm{pH}$ was more punctate. This was likely related to the organization of focal adhesion plaques and how they assemble for migration (Wahl and Grant, 2002). Other microenvironmental parameters have not been evaluated in terms of this receptor and these factors have not been evaluated for other anti-angiogenic agents.

\section{F. HYPOXIA}

Hypoxia often - but not always - goes hand in hand with acidity, although there is some disparity in spatial distribution (Vaupel et al., 1989,1998; Brizel et al., 1996; Gullege and Dewhirst, 1996; Helmlinger et al., 1997). These two features have not been teased apart experimentally to determine the relative importance of each and the degree of overlap. Most studies thus far are either conducted at low $\mathrm{pH}$ or done under hypoxic conditions but not both. Future studies with new anti-angiogenic agents, such as 2-methoxyestradiol (2ME2) or Panzem ${ }^{\circledR}$ (Entremed, Inc.), a hypoxia-inducible factor (HIF)-1 $\alpha$ inhibitor (Mabjeesh et al., 2003), will help determine the extent to which targeting this receptor will be useful in a variety of tumor types. There is evidence that hypoxia is a feature of diabetic complications such as renal disease (Ries et al., 2003), poor circulation in lower extremities (Fife et al., 2002), and retinopathy (Drasdo et al., 2002).

\section{G. BICARBONATE STATUS}

Bicarbonate $\left(\mathrm{HCO}_{3}{ }^{-}\right)$is a parameter that has not been considered in most in vitro work but should receive more attention. In the tumor microenvironment, catabolite removal by inefficient and abnormal blood vessels is poor, resulting in $\mathrm{CO}_{2}$ buildup (Newell et al., 1993; Helminger et al., 2002). Both these aspects contribute to the low $\mathrm{pH}$ environment. In some work at low $\mathrm{pH}$, the $\mathrm{pH}$ is lowered by altering sodium bicarbonate concentration (Chu and Dewey, 1988; Chu et al., 1990; Wahl et al., 1996; Owen et al., 1997). In this type of experiment, the buffering capacity of the medium will be low, causing more potential extracellular $\mathrm{pH}$ fluctuation. Furthermore, this approach has two experimental variables, $\mathrm{pH}$ and bicarbonate, without distinction as to which is causing the effects on cells in the tumor microenvironment. Research studies have been performed where bicarbonate is maintained at $26 \mathrm{mM}$ and the incubator $\mathrm{CO}_{2}$ is raised to $17 \%$ from $5 \%$, to create acidic and tumor-like conditions (Wahl and Grant, 2002; Wahl et al., 2002a,b). This is an appealing model, since physiologic bicarbonate is 26 $\mathrm{mM}$ and the tumor is high in $\mathrm{CO}_{2}$, which is a likely cause of elevated carbonic 
anhydrase levels in tumors (Beasley et al., 2001; Giatromanolaki et al., 2001; Koukourakis et al., 2001; Olive et al., 2001; Bui et al., 2003; Swinson et al., 2003). It has been proposed that carbonic anhydrase inhibitors could relax pericytes, cause vasodilation, and enhance blood supply to the retina by increasing intracellular $\mathrm{pH}$ and decreasing extracellular $\mathrm{pH}$ (Reber et al., 2003). It would be even more physiologic to study tumor cell behavior in a hypoxic chamber inside a $17 \% \mathrm{CO}_{2}$ incubator, to further mimic the part of the tumor microenvironment most likely to promote new blood vessel branch growth. Evaluation of low extracellular $\mathrm{pH}$, low oxygen, and the combination in terms of therapeutic responses to agents and phenotype of cells in such environments should help characterize responses in the tumor microenvironment more completely.

\section{H. LACTIC ACIDOSIS}

Another reason, other than high $\mathrm{CO}_{2}$ and poor perfusion, for the acidic microenvironment in tumors is excessive production of lactic acid (Vaupel et al., 1989; Walenta et al., 1997; Brizel et al., 2001; Wahl et al., 2002b). One indicator of the contribution of lactic acidosis is measuring levels of the transporter used to remove it from the cell. This transporter, MCT, is elevated in human melanoma (Wahl et al., 2002b) and may be elevated in other tumors of neural crest origin, including brain tumors. MCT levels are elevated in the retina of diabetics, indicative of elevated lactic acid in that compartment (Knott et al., 1999). Intracellular and extracellular $\mathrm{pH}$ levels, functionality of other transporters used to regulate intracellular $\mathrm{pH}$, and degree to which MCT is elevated may be critical to understanding the degree to which a $\mathrm{pH}$ regulation inhibitor can affect a certain cell type and to which angiostatin can affect intracellular $\mathrm{pH}$ in endothelial cells in the low $\mathrm{pH}$ tumor microenvironment. Intracellular and extracellular $\mathrm{pH}$ measurements in normal and pathologic body compartments aside from the tumor microenvironment will help address the relative importance of these parameters. In addition, a relationship between areas of hypoxia and acidity is likely, although the relative importance of each has not been addressed in any one study.

\section{GLUCOSE, HYPERGLYCEMIA \& ACIDIFICATION}

Oral glucose is used clinically to lower tumor $\mathrm{pH}$ before thermoradiotherapy (Thistlethwaite et al., 1987; Leeper et al., 1994,1998; Engin et al., 1995). The mechanism is via increased glycolysis in the tumor microenvironment, producing lactic acid (Burd et al., 2001). In diabetes, glucose overload may occur, so the

patient's tissues already may be more acidic. This could lead to potentiation of angiostatin's activity in the body, since its activity is greatest when $\mathrm{pH}$ is low (Wahl and Grant, 2002; Wahl et al., 2002a). Other enzymes relating to glycolysis may impact this axis, including lactate dehydrogenase (Koslowski et al., 2002), 
glut-1 receptor levels (Thews et al., 2003), and hexokinase levels (Wachsberger et al., 2002). In the diabetic, it is believed that complications arise to a greater extent in patients with the most poorly managed glucose levels (DCCT Research Group, 1993), although this is still a matter of considerable debate (Craighead, 1994). Individual variations in glycation (non-enzymatic glycosylation) of proteins are not only affected by degree of management but also by other unknown parameters. Facchiano and coworkers (2002) have reported that FGF (isoform 2) is more glycosylated in diabetic mice and is less chemotactic and pro-angiogenic as a result.

\section{J. MATRIX}

Matrix composition could be used to distinguish physiologic compartments, if qualitative and/or quantitative differences can be characterized in nondiabetics and diabetics with and without cancer. With respect to angiostatin, research indicates that the vulnerability of endothelial cells in the tumor microenvironment stems in part from the fact that when they are rapidly proliferating, their attachments are compromised. Furthermore, substrates they come in contact with in the tumor microenvironment differ, leading to different integrin isoform expression, with subsequent differences in signal transduction. This would contribute to the explanation of why mature vessels appear to be unaffected by angiostatin. It also would explain the targeting of endostatin to integrins (Sudhakar et al., 2003), which then would be less apt to be engaged in attachment. Migration of tumor cells is often along the ECM of the basal lamina. When mice are injected with a melanoma cell line selected for metastatic seeding in the lung, the cells migrate specifically and secondary lung tumors are formed. When they are inhibited from binding fibronectin or laminin, over $90 \%$ of the cells fail to reach the lungs (Humphries et al., 1986). In order to enter a blood vessel, tumor cells lyse the collagenous matrix by secreting various plasminogen activators. Antibodies directed against plasminogen activators have been shown to inhibit metastasis (Ossowski and Reich, 1983). The urinary-type plasminogen activation complex (u-PA) is one of the major regulators of ECM remodeling. u-PA converts plasminogen to plasmin, which degrades matrix and indirectly activates other metalloproteinases (Vassalli et al., 1991). Enriched levels of u-PA and its receptor (u-PAR) are found on the leading edge of migrating cells. Plasminogen activator inhibitor type 1 (PAI-1), a u-PA antagonist, mediates cell adhesion and spreading by forming a bridge between the cell surface and the matrix directly regulating adhesion (Planus et al., 1997). u-PA expression has been correlated with angiogenesis and poor prognosis (Kaneko et al., 2003).

Matrix metalloproteinases (MMP) are enzymes that digest/degrade matrix proteins, enabling metastasizing cells to migrate. Matrix metalloproteinase inhibitors (MMPI) exist in a balance and can be offset in pathologic conditions 
(Spranger et al., 2000). Another factor warranting further study is the composition of matrix in various locations, which will affect the degree of enzyme activity needed to impact upon the matrix. A third consideration is that enzymatic alteration of matrix composition may affect where tumor cells disseminate and may cause digestion of other pathologic matrices in nearby or distant areas. This issue may require consideration in glomerulosclerosis and other complications of diabetes in which basement membrane thickening is a feature. Finally, MMP/ MMPI balance may affect wound healing, an important consideration for patients that may need surgery during their course of treatment (Lockhart et al., 2003).

\section{K. TUMOR VESSEL ARCHITECTURE}

Tumor blood vessel branches are inefficient and tortuous. In tumor vessels, backflow often occurs, mixing arterial and venous blood, and vessels leak (Secomb et al., 1993; McDonald and Baluk, 2002). Some of these characteristics are potentially exploitable by anti-angiogenic agents and antivascular agents, again, hopefully, with some specificity for the uniquely abnormal features of these vessels. More studies are needed to characterize vasculature in different tumor types, as a function of different body locations of metastasis, and the degree of resemblance to other vasculature in normal and pathologic instances that can coexist in patients.

\section{Models Used to Study Angiogenesis in Various Tissues}

\section{A. IN VITRO MODELS}

Many cell types are used to study angiogenesis from macrovascular vessels, microvascular vessels, various locations in the body, and from various animal species. Although little information is available about the differences between these various cell types, these differences are extremely important if research findings are to be translated into practical, predictive information. Models include the tube differentiation assay (Kubota et al., 1988; Grant et al., 1990,1995; Grant and Kleinman, 1997), the migration/scratch assay, and the rat aortic ring assay (Nicosia and Ottinetti, 1990; Grant and Kleinman, 1997). For angiostatin, data have been confirmed in all three of these models (Wahl et al., 2002a). However, for other agents, one system may demonstrate activity more than another, which will lead to elucidation of what models may be most useful for which agents or diseases. Physiologic models are critical to getting meaningful results. 


\section{B. ANIMAL MODELS}

Several animal models are available to study angiogenesis, including the corneal pocket (Muthukkaruppan and Auerback, 1970; O'Reilly et al., 1994b; Sood et al., 1999), the chick embryo (Risau and Lemmon, 1988; O'Reilly et al., 1994b; Eriksson et al., 2003), implantation of human cells into a mouse or a rat (xenografts) in various locations (Danielsen and Rofstad, 2000; Shan et al., 2003), and the angioreactor model (Guedez et al., 2003). Which are best to model which tumor types and clinical scenarios? Considerations include the fact that blood vessels in a human xenograft usually are a combination of human and animal vessels. Tumors often are placed in animals in locations other than the ones where they naturally occur. Model evaluation is critical to determining which one may be most physiologically meaningful. A knowledge of the pathogenesis of the particular type of cancer, the degree of vascularity it possesses, and the microenvironment of the location into which it will be grafted are all critical considerations.

\section{DESIGN OF CLINICAL TRIALS: TIMING IS EVERYTHING}

In the angiostatin phase I clinical trial at Thomas Jefferson University, wound healing was normal in a patient needing acute unexpected surgery while on angiostatin (DeMoraes et al., 2001). Other anti-angiogenic agents may differ, however, so this must be considered, preferably prior to introduction of agents in the clinic. Another consideration in trials is that the typical measure of efficacy - tumor growth delay assessments - may not be perfectly applicable to anti-angiogenic drugs. Some are initially slow to show responses (D'Amato et al., 1994). Others may cause necrosis followed by swelling, which is mostly inflammatory cells and fluid. Thus, even though a large part of the tumor mass is killed, the initial effect is an apparent increase in tumor size (Kaban et al., 1999). Most traditional therapies are directed at achieving maximum results during a brief window of opportunity, while most anti-angiogenic therapies will need to be administered chronically and indefinitely to prevent blood vessel branches from sprouting (Kaban et al., 1999). Therefore, animal model experiments will have to be designed to take these differences into account.

The parameters described above are emerging as important for cancer pathogenesis and treatment outcome, yet most are not considered during experimental work on anti-angiogenic drugs. Conversely, when pro-angiogenic drugs are administered for other conditions, patients with neoplastic disease may have counter-indications. Some of these drugs are listed in Table II.

\section{Diabetes}

Some sequelae of diabetes mellitus include impaired wound healing, characterized by both spontaneous and wound-induced ulcerations, particularly of the 
MIRIAM L. WAHL ET AL.

TABLE II

Pro-angiogenic Agents

\begin{tabular}{|c|c|c|c|}
\hline Drug & Target & $\begin{array}{l}\text { Approved or potential } \\
\text { use }\end{array}$ & References \\
\hline $\begin{array}{l}\text { Regranex } \\
\quad \text { (becaplurmin) }\end{array}$ & Unknown & $\begin{array}{c}\text { Diabetic foot ulcers } \\
\text { (Ortho-McNeil } \\
\text { Pharmaceuticals) }\end{array}$ & Fruhstorfer, 2000 \\
\hline SIKVAV & Unknown & $\begin{array}{l}\text { Cardiovascular ischemia } \\
\text { prevention }\end{array}$ & Grant and Zukowska, 2000 \\
\hline Angiopoietin I & $\begin{array}{l}\text { Tie-2 on } \\
\text { endothelial cells }\end{array}$ & $\begin{array}{l}\text { Cardiovascular ischemia } \\
\text { prevention }\end{array}$ & $\begin{array}{l}\text { Cascone } \text { et al., 2003; } \\
\quad \text { Fiedler } \text { et al., } 2003\end{array}$ \\
\hline Angiopoietin II & $\begin{array}{l}\text { Tie-2 on } \\
\text { endothelial cells }\end{array}$ & $\begin{array}{l}\text { Cardiovascular ischemia } \\
\text { prevention }\end{array}$ & $\begin{array}{l}\text { Fiedler } \text { et al., 2003; Zhang } \\
\quad \text { et al., } 2003\end{array}$ \\
\hline Neuropeptide Y & NPY2 & Wound healing & $\begin{array}{l}\text { Grant and Zukowska, 2000; } \\
\text { Ekstrand et al., 2003; } \\
\text { Lee et al., } 2003\end{array}$ \\
\hline
\end{tabular}

lower limbs, and retinopathy. Both these conditions are consequences of insufficient perfusion. If limbs become acidotic and hypoxic, why don't they invoke the growth of new and normal blood vessels? Do they produce compounds that antagonize angiogenesis (e.g., angiostatin, endostatin) in higher amounts than those that promote it (e.g., VEGF, FGF) initially, then not turn off those signals at the right time? If so, exogenous administration of either type of compound could make things worse. With retinopathy, hypervascularization occurs at later stages, where there could be a positive impact from anti-angiogenic therapy. All potential side effects should be evaluated in diabetics, whether or not they have complications, since the eventual complication rate is high. Those that are known to have a vascular component are discussed in the following sections.

\section{A. RETINOPATHY}

Retinopathy, followed by macular degeneration, develops in $50-98 \%$ of diabetics within 15 years of diagnosis and is the most-devastating complication. It is characterized by basement membrane thickening, pericyte degeneration, microaneurysm formation, and focal capillary closure and acellularity, with subsequent abnormal proliferation of endothelial cells. Although laser treatment can prevent blindness in most cases, vitreous cavity bleeding and retinal detachment are problematic and preventative therapies would be more desirable (Danis et al., 2001). 
Among those issues being investigated are the effects of chronic intracellular hyperglycemia and abnormal glycation (Kaban et al., 1999; Noma et al., 2002; Verstappen et al., 2003), disturbances in the polyol pathway (Funatsu et al., 2003), and protein glycation (Funatsu et al., 2002). All sugars, including D-glucose and D-galactose, can initiate protein glycation. They produce stable adducts that accumulate on long-lived biological molecules such as hemoglobin and proteins of the extracellular matrix (e.g., collagen). The rate of this reaction increases with glucose concentration. When basement membranes were glycated heavily in vitro, increased proliferation of endothelial cells and decreased proliferation of pericytes was reported (Kalfa et al., 1995; Beltramo et al., 2003). Synergistic effects of diabetes and hypertension have been reported in an animal model and increased number of caveolae in endothelial cells and pericytes, basement membrane thickening, and decreased cell-cell contact (Hillman et al., 2001). As the most metabolically active tissue in the body, the retina has a high demand for oxygen. In diabetes, capillaries supplying the retina may become clogged, resulting in oxygen deprivation (Barinaga, 1995). The retina then produces VEGF but the vessels don't form in a proper or orderly manner. A similar process happens in premature infants. If this abnormal development could be stopped or re-directed, the blindness that often ensues could be preventable. One successful approach to therapy for retinopathy is photocoagulation. After this therapy was administered to diabetic retinas, endogenous angiostatin release was detected, which likely contributes to the success of the treatment (Spranger et al., 2000). Some studies have linked high production of VEGF and low production of endostatin with severity of diabetic retinopathy (Noma et al., 2002), diminished benefits from surgical intervention to treat cataracts (Funatsu et al., 2003), and increased risk of macular edema (Funatsu et al., 2002). Inflammatory mechanisms may influence retinal neovascularisation. Induction of cyclooxygenase- 2 inhibitors has been shown to inhibit it by antagonizing prostaglandin E2 (Sennlaub et al., 2003).

\section{B. ULCERATIONS AND DRY GANGRENE}

Ulceration and dry gangrene occur in diabetes due to insufficiency of circulation to the lower limbs. What is the mechanism by which this hypovascularity develops? Is there a lack of pro-angiogenic cues or responses to them or counterbalancing anti-angiogenic factors? Recently, Regranex (Ortho MacNeil Pharmaceuticals, Raritan, NJ) was approved for use in combating circulation impairment in the lower extremities. It is important to keep in mind that if a person had an undiagnosed cancer at the time of treatment, his/her malignant condition could be made worse as a result of treatment. 


\section{OTHER COMPLICATIONS}

Other complications in which the role of angiogenesis is unknown include glomerulosclerosis, necrotizing papillitis, focal demyelination, and peripheral neuropathy. Peripheral neuropathy is also a side effect of some chemotherapeutic drugs (Verstappen et al., 2003); thus, alternatives to these should be prescribed for diabetic cancer patients. Neuropathy may be related to the polyol pathway, in which aldose reductase and sorbitol dehydrogenase are the two key enzymes that handle excess glucose by converting it to sorbitol (Oates, 2002). Sorbitol toxicity has been implicated in neuron, kidney, and retinal damage. It may act by creating an osmotic gradient leading to swelling or have direct toxicities (Craighead, 1994). Diabetics have impaired wound healing, increased rejection of transplanted organs, and impaired formation of coronary collaterals, all of which have the lack of angiogenesis in common.

\section{Understanding the Basis for Selectivity Is the Key to Prudent Trial Design}

Anti-angiogenic therapies for cancer patients are most desirable if they don't inhibit wound healing. Conversely, development of pro-angiogenic drugs for diabetics that work well in the retina and wounds but don't stimulate tumor growth is needed. Combination therapies that aren't antagonistic can be developed only if there is detailed analysis of the microenvironment and cell types in the different physiologic and pathologic compartments of the patient, so the desirable selectivity can be achieved and undesirable side effects can be avoided. The key is selectivity as a function of cell type, microenvironment, and for the various pathologies in which abnormal vascularity is a feature.

Much remains to be learned about the mechanisms for selectivity of antiangiogenic agents in the tumor microenvironment and other locations. There is evidence that the tumor microenvironment is acidotic, hypoxic, and pro-angiogenic, so it could follow that $\mathrm{pH}$ or oxygen elevation could enhance effects in desired locations for pro-angiogenesis. Could impairment of intracellular $\mathrm{pH}$ regulation be causative in the etiology of the reduced perfusion in the limbs of diabetics? If it is compromised, how? There may be abnormalities in $\mathrm{pH}$ regulation in the diabetic retina or the ulcerative wound. If so, could counteractive drugs be developed that stimulate ion transport and encourage angiogenesis? Another aspect of drug potency is $\mathrm{pH}$-dependent activity. Many features must be taken into account to understand the interactions that will lead to a positive, negative, or no effect for each agent.

\section{Conclusions}

In summary, concepts are emerging from research reported on the mechanism of action and basis for specificity of angiostatin. The data indicate that the 
many new anti-angiogenic agents that have been developed and tested need to be characterized in terms of microenvironmental influences that affect their activity and other undesirable actions in other types of tissue, in patients with and without secondary pathologies. This chapter delineates some of activity parameters for this class of agents that are needed to enable effective translation to the clinic, with predictive information regarding harmful side effects, so that patients at risk can be handled accordingly.

\section{ACKNOWLEDGMENTS}

This work was supported by U.S. Public Health Service Grant CA-59960 (M.L.W.) and National Cancer Institute CA86344 (S.V.P.). The authors would like to thank collaborators who contributed to the research described herein. These include Roderick A. Capaldi, Robert L. Capizzi, Adam P. Dicker, Judah Folkman, David W. Golde, Derrick S. Grant, Andrew P. Halestrap, Dennis B. Leeper, Charles S. Owen, and Judith A. Owen. The authors thank Steve Conlon, Robert W. Veneziale, and Soman N. Abraham for contributions towards artwork in Figures 1-4.

\section{REFERENCES}

Agarwala SS, Kirkwood JM 2003 Temozolomide in combination with interferon $\alpha$-2b in patients with metastatic melanoma: a phase I dose-escalation study. Cancer 97:121-127

Agius E, Sagot Y, Duprat AM, Cochard P 1996 Antibodies directed against the $\beta 1$-integrin subunit and peptides containing the IKVAV sequence of laminin perturb neurite outgrowth of peripheral neurons on immature spinal cord substrata. Neuroscience 71:773-786

Akasaka T, vanLeeuwen RL, Yoshinaga IG, Mihm MC, Byers HR 1995 Focal adhesion kinase $\left(\mathrm{p} 125^{\mathrm{FAK}}\right)$ expression correlates with motility of human melanoma cell lines. J Invest Dermatol 105:104-108

Akhter S, Nath SK, Tse CM, Williams J, Zasloff M, Donowitz M 1999 Squalamine, a novel cationic steroid, specifically inhibits the brush-border $\mathrm{Na}^{+} / \mathrm{H}^{+}$exchanger isoform NHE3. Am J Physiol 276:C136-C144

Albanell J, Rojo F, Averbuch S, Feyereislova A, Mascaro JM, Herbst R, LoRusso P, Rischin D, Sauleda S, Gee J, Nicholson RI, Baselga J 2002 Pharmacodynamic studies of the epidermal growth factor receptor inhibitor ZD1839 in skin from cancer patients: histopathologic and molecular consequences of receptor inhibition. J Clin Oncol 20:110-124

Allt G, Lawrenson JG 2001 Pericytes: cell biology and pathology. Cells Tiss Organs 169:1-11

Aoudjit F, Vuori K 2001 Matrix attachment regulates Fas-induced apoptosis in endothelial cells: a role for c-flip and implications for anoikis. J Cell Biol 152:633-643

Arakaki N, Nagao T, Niki R, Toyofuku A, Tanaka H, Kuramoto Y, Emoto Y, Shibata H, Magota K, Higuti T 2003 Possible role of cell surface $\mathrm{H}^{+}$-ATP synthase in the extracellular ATP synthesis and proliferation of human umbilical vein endothelial cells (HUVECs). Mol Cancer Res 1:931-939

Baatout S, Cheta N 1996 Matrigel: a useful tool to study endothelial differentiation. Rom J Intern Med 34:263-269

Baidas SM, Winer EP, Fleming GF, Harris L, Pluda JM, Crawford JG, Yamauchi H, Isaacs C, Hanfelt J, Tefft M, Flockhart D, Johnson MD, Hawkins MJ, Lippman ME, Hayes DF 2000 Phase II evaluation of thalidomide in patients with metastatic breast cancer. J Clin Oncol $18: 2710-2717$ 
Barinaga M 1995 Shedding light on blindness. Science 267:452-453

Baselga J, Rischin D, Ranson M, Calvert H, Raymond E, Kieback DB, Kaye SB, Gianni L, Harris A, Bjork T, Averbuch SD, Feyereislova A, Swaisland H, Rojo F, Albanell J 2002 Phase I safety, pharmacokinetic, and pharmacodynamic trial of ZD1839, a selective oral epidermal growth factor receptor tyrosine kinase inhibitor, in patients with five selected solid tumor types. J Clin Oncol 20:4292-4302

Batist G, Patenaude F, Champagne P, Croteau D, Levinton C, Hariton C, Escudier B, Dupont E 2002 Neovastat (AE-941) in refractory renal cell carcinoma patients: report of a phase II trial with two dose levels. Ann Oncol 13:1259-1263

Beasley NJ, Wykoff CC, Watson PH, Leek R, Turley H, Gatter K, Pastorek J, Cox GJ, Ratcliffe P, Harris AL 2001 Carbonic anhydrase IX, an endogenous hypoxia marker, expression in head and neck squamous cell carcinoma and its relationship to hypoxia, necrosis, and microvessel density. Cancer Res 61:5262-5257

Beltramo E, Buttiglieri S, Pomero F, Allione A, D'Alu F, Ponte E, Porta M 2003 A study of capillary pericyte viability on extracellular matrix produced by endothelial cells in high glucose. Diabetologia 46: 409-415

Benelli R, Morini M, Carrozzino F, Ferrari N, Minghelli S, Santi L, Cassatella M, Noonan DM, Albini A 2002 Neutrophils as a key cellular target for angiostatin: implications for regulation of angiogenesis and inflammation. FASEB J 16:267-269

Bergers G, Song S, Meyer-Morse N, Bergsland E, Hanahan D 2003 Benefits of targeting both pericytes and endothelial cells in the tumor vasculature with kinase inhibitors. J Clin Invest 111:1277-1280

Bhargava P, Marshall JL, Bahut W, Rizvi N, Tocky N, Williams JI, Hait H, Song S, Holroyd KJ, Hawkins MJ 2001 A phase I and pharmacokinetic study of squalamine, a novel antiangiogenic agent, in patients with advanced cancers. Clin. Cancer Res 7:3912-3919

Bier H, Reiffen KA, Haas I, Stasiecki P 1995 Dose-dependent access of omurine anti-epidermal growth factor receptor monoclonal antibody to tumor cells in patients with advanced laryngeal and hypopharyngeal carcinoma. Eur Arch Otorhinolaryngol 252:433-439

Boyer MJ, Tannock IF 1992 Regulation of intracellular pH in tumor cell lines: influence of microenvironmental conditions. Cancer Res 52:4441-4447

Braybrooke JP, O'Byrne KJ, Propper DJ, Blann A, Saunders M, Dobbs N, Han C, Woodhull J, Mitchell K, Crew J, Smith K, Stephens R, Ganesan TS, Talbot DC, Harris AL 2000 A phase II study of razoxane, an antiangiogenic topoisomerase II inhibitor, in renal cell cancer with assessment of potential surrogate markers of angiogenesis. Clin Cancer Res 6:46974704

Brewer GJ, Dick RD, Grover DK, LeClaire V, Tseng M, Wicha M, Pienta K, Redman BG, Jahan T, Sondak VK, Strawderman M, LeCarpentier G, Merajver SD 2000 Treatment of metastatic cancer with tetrathiomolybdate, an anticopper, antiangiogenic agent: phase I study. Clin Cancer Res 6:1-10

Brivio F, Lissoni P, Rovelli F, Nespoli A, Uggeri F, Fumagalli L, Gardani G 2002 Effects of IL-2 preoperative immunotherapy on surgery-induced changes in angiogenic regulation and its prevention of VEGF increase and IL-12 decline. Hepatogastroenterology 49:385-387

Brizel DM, Scully SP, Harrelson JM, Layfield LJ, Bean JM, Prosnitz LR, Dewhirst MW 1996 Tumor oxygenation predicts for the likelihood of distant metastases in human soft tissue sarcoma. Cancer Res 56:941-943

Brizel DM, Schroeder T, Scher RL, Walenta S, Clough RW, Dewhirst MW, Mueller-Klieser W 2001 Elevated tumor lactate concentrations predict for an increased risk of metastases in head-and-neck cancer. Intl J Radiat Oncol Biol Phys 51:349-353

Bui MH, Seligson D, Han KR, Pantuck AJ, Dorey FJ, Huang Y, Horvath S, Leibovich BC, Chopra S, Liao SY, Stanbridge E, Lerman MI, Palotie A, Figlin RA, Belldegrun AS 2003 
Carbonic anhydrase IX is an independent predictor of survival in advanced renal clear cell carcinoma: implications for prognosis and therapy. Clin Cancer Res 9:802-811

Burd R, Wachsberger PR, Biaglow JE, Wahl ML, Leeper DB 2001 Absence of Crabtree effect in human melanoma cells adapted to growth at low $\mathrm{pH}$ : reversal by respiratory inhibitors. Cancer Res 61:5630-5635

Canfield AE, Schor AM, Schor SL, Grant ME 1986 The biosynthesis of extracellular-matrix components by bovine retinal endothelial cells displaying distinctive morphological phenotypes. Biochem J 235:375-383

Cao Y, Veitonmaki N, Keough K, Cheng H, Lee LS, Zurakowski D 2000 Elevated levels of urine angiostatin and plasminogen/plasmin in cancer patients. Intl J Mol Med 5:547-551

Cascone I, Audero E, Giraudo E, Napione L, Maniero F, Philips MR, Collard JG, Serini G, Bussolino F 2003 Tie-2-dependent activation of RhoA and Rac1 participates in endothelial cell motility triggered by angiopoietin-1. Blood 102:2482-2490

Chen HX, Gore-Langton RE, Cheson BD 2001 Clinical trials referral resource: current clinical trials of the anti-VEGF monoclonal antibody bevacizumab. Oncology 15:1017-1026

Chu G, Dewey WC 1988 The role of low intracellular or extracellular pH in sensitization to hyperthermia. Radiat Res 114:154-167

Chu GL, Wang Z, Hyun W, Pershadingh H, Fulwyler M, Dewey WC 1990 The role of intracellular $\mathrm{pH}$ and its variance in low $\mathrm{pH}$ sensitization of killing by hyperthermia. Radiat Res 122:288-293

Claesson-Welsh L, Welsh M, Ito N, Ananda-Apte B, Soker S, Zetter B, O'Reilly M, Folkman J 1998 Angiostatin induces endothelial cell apoptosis and activation of focal adhesion kinase independently of the integrin-binding motif RGD. Proc Natl Acad Sci USA 95:5579-5583

Colorado PC, Torre A, Kamphaus G, Maeshima Y, Hopfer H, Takahashi K, Volk R, Zamborsky ED, Herman S, Sarkar PK, Ericksen MB, Dhanabal M, Simons M, Post M, Kufe DW, Weichselbaum RR, Sukhatme VP, Kalluri R 2000 Anti-angiogenic cues from vascular basement membrane collagen. Cancer Res 1:2520-2526

Coopman PJ, Thomas DM, Gehlsen KR, Mueller SC 1996 Integrin $\alpha 3 \beta 1$ participates in the phagocytosis of extracellular matrix molecules by human breast cancer cells. Mol Biol Cell 7:1789-1804

Craighead JE 1994 Diabetes. In: Rubin E, Farber J, eds. Pathology, chap 22. Philadelphia: J.B. Lippincott Co.; $1148-1160$

Daliani DD, Papandreous CN, Thall PF, Wang X, Perez C, Oliva R, Pagliaro L, Amato R 2002 A pilot study of thalidomide therapy in refractory solid tumour patients. Cancer 95:758-765

D'Amato RJ, Loughnan MS, Flynn E, Folkman J 1994 Thalidomide is an inhibitor of angiogenesis. Proc Natl Acad Sci USA 91:4082-4085

Danielsen T, Rofstad EK 2000 The constitutive level of vascular endothelial growth factor (VEGF) is more important than hypoxia-induced VEGF up-regulation in the angiogenesis of human melanoma xenografts. Br J Cancer 82:1528-1534

Danis RP, Ciulla TA, Criswell M, Pratt L 2001 Anti-angiogenic therapy of proliferative diabetic retinopathy. Expert Opin Pharmacother 2:395-407

DCCT Research Group 1993 The effect of intensive treatment of diabetes on the development and progression of long-term complications in insulin-dependent diabetes mellitus. N Engl J Med 329:977-986

DeMoraes ED, Fogler WE, Grant DS, Wahl ML, Leeper DB, Zrada S, Malin A, Connors S, Fortier AH, Dabrow M, Sidor C, Capizzi RL 2001 Recombinant human angiostatin (rhA): a phase I clinical trial assessing safety, pharmacokinetics (PK) and pharmacodynamics (PD). In: Abstracts of the $37^{\text {th }}$ Annual Meeting of the American Society for Clinical Oncology. May 12-15, San Francisco, abstract 10 
Dinney CP, Bielenberg DR, Perrotte P, Reich R, Eve BY, Bucana CD, Fidler IJ 1998 Inhibition of basic fibroblast growth factor expression, angiogenesis, and growth of human bladder carcinoma in mice by systemic interferon- $\alpha$ adminstration. Cancer Res 58:808-814

Drasdo N, Chiti Z, Owens DR, North RV 2002 Effect of darkness on inner retinal hypoxia in diabetes. Lancet 359:2251-2253

Dvorak HF, Nagy JA, Dvorak JT, Dvorak AM 1988 Identification and characterization of the blood vessels of solid tumors that are leaky to circulating macromolecules. Am J Pathol 133:95-109

Eckhardt SG, Burris HA, Eckardt JR, Weiss G, Rodriguez G, Rothenberg M, Rinaldi D, Barrington R, Kuhn JG, Masuo K, Sudo K, Atsumi R, Oguma T, Higashi L, Fields S, Smetzer L, Von Hoff DD 1996 A phase I clinical and pharmacokinetic study of the angiogenesis inhibitor, tecogalan sodium. Ann Oncol 7:491-496

Eckhardt SG, Rizzo J, Sweeney KR, Cropp G, Baker SD, Kraynak MA, Kuhn JG, VillalonaCalero MA, Hammond L, Weiss G, Thurman A, Smith L, Drengler R, Eckardt JR, Moczygemba J, Hannah AL, Von Hoff DD, Rowinsky EK 1999 Phase I and pharmacologic study of the tyrosine kinase inhibitor SU101 in patients with advanced solid tumors. J Clin Oncol 17:1095-1104

Eder JP, Supko JG, Clark JW, Puchalski TA, Garcia-Carbonero R, Ryan DP, Shulman LN, Proper J 2002 Phase I clinical trial of recombinant human ednostatin administered as a short intravenous infusion repeated daily. J Clin Oncol 20:3772-3784

Egginton S, Zhou AL, Brown MD, Hudlicka O 2000 The role of pericytes in controlling angiogenesis in vivo. Adv Exp Med Biol 476:81-99

Ekstrand AJ, Cao R, Bjorndahl M, Nystrom S, Jonsson-Rylander AC, Hassani H, Hallberg B, Nordlander M, Cao Y 2003 Deletion of neuropeptide Y (NPY) 2 receptor in mice results in blockage of NPY-induced angiogenesis and delayed wound healing. Proc Natl Acad Sci USA 100:6033-6038

Engin K, Leeper DB, Cater JR, Thistlethwaite AJ, Tupchong L, McFarlane JD 1995 Extracellular $\mathrm{pH}$ distribution in human tumours. Intl J Hyperthermia 11:211-216

Erdreich-Epstein A, Shimada H, Groshen S, Liu M, Metelitsa LS, Kim KS, Stins MF, Seeger RC, Durden DL 2000 Integrins $\alpha_{\mathrm{v}} \beta_{3}$ and $\alpha_{\mathrm{v}} \beta_{5}$ are expressed by endothelium of high-risk neuroblastoma and their inhibition is associated with increased endogenous ceramide. Cancer Res 60:712-721

Eriksson K, Magnusson P, Dixelius J, Claesson-Welsh L, Cross MJ 2003 Angiostatin and endostatin inhibit endothelial cell migration in response to FGF and VEGF without interfering with specific intracellular signal transduction pathways. FEBS Lett 536:19-24

Escudier B, Lassau N, Couanet D, Angevin E, Mesrati F, Leborgne S, Garofano A, Leboulaire C, Dupouy N, Laplanche A 2002 Phase II trial of thalidomide in renal-cell carcinoma. Ann Oncol 13:1029-1035

Facchiano F, Lentini A, Fogliano V, Mancarella S, Rossi C, Facchiano A, Capogrossi MC 2002 Sugar-induced modification of fibroblast growth factor 2 reduces its angiogenic activity in vivo. Am J Pathol 161:531-541

Fett JW, Strydom DJ, Lubb RR, Adlerman EM, Bethune JL, Riordan JF, Vallee BL 1985 Isolation and characterization of angiogenin, an angiogenic protein from human carcinoma cells. Biochemistry 24:5480-5486

Fiedler U, Krissl T, Koidl S, Weiss C, Koblizek T, Deutsch U, Martiny-Baron G, Marme D, Augustin HG 2003 Angiopoietin-1 and angiopoietin-2 share the same binding domains in the Tie-2 receptor involving the first Ig-like loop and the epidermal growth factor-like repeats. J Biol Chem 278:1721-1727

Fife CE, Buyukcakir C, Otto GH, Sheffield PJ, Warriner RA, Love TL, Mader J 2002 The predictive value of transcutaneous oxygen tension measurement in diabetic lower extremity 
ulcers treated with hyperbaric oxygen therapy: a retrospective analysis of 1,144 patients. Wound Repair Regen 10:198-207

Figg WD, Arlen P, Gulley J, Fernandez P, Noone M, Fedenko K, Hamilton M, Parker C, Kruger EA, Pluda J, Dahut WL 2001 A randomized phase II trial of docetaxel (taxotere) plus thalidomide in androgen-independent prostate cancer. Semin Oncol 28:62-66

Folkman J 1971 Tumor angiogenesis: therapeutic implications. N Engl J Med 285:1182-1186

Fortier AH, Fogler WE, Ruiz A, Kough E, Sim BKL 2001 Daily dosing of monkeys with recombinant human angiostatin for 90 consecutive days is safe. In: Abstracts of the $37^{\text {th }}$ Annual Meeting of the American Society for Clinical Oncology. May 12-15, San Francisco, abstract 2144

Fruhstorfer B 2000 Approval for recombinant growth factor. Since January 2000, patients with diabetic foot ulcers can be treated with the growth factor becaplermin (Regranex), manufactured with genetic technology. Internist (Berl) 41:A38

Funatsu H, Yamashita H, Noma H, Shimizu E, Mimura T, Hori S 2002 Prediction of macular edema exacerbation after phacoemulsification in patients with nonproliferative diabetic retinopathy. J Cataract Refract Surg 28:1355

Funatsu H, Yamashita H, Noma H, Mochizuki H, Mimura T, Ikeda T, Hori S 2003 Outcome of vitreous surgery and the balance between vascular endothelial growth factor and endostatin. Invest Ophthalmol Vis Sci 44:1042-1047

Galbraith SM, Rustin GJ, Lodge MA, Taylor NJ, Stirling JJ, Jameson M, Thompson P, Hough D, Gumbrell L, Padhani AR 2002 Effects of 5,6-dimethylxanthenone-4-acetic acid on human tumor microcirculation assessed by dynamic contrast-enhanced magnetic resonance imaging. J Clin Oncol 20:3826-3840

Gately S, Twardowski P, Stack MS, Patrick M, Boggio L, Cundiff DL, Schnaper HW, Madison L, Volpert O, Bouck N, Enghild J, Kwaan HC, Soff GA 1996 Human prostate carcinoma cells express enzymatic activity that converts human plasminogen to the angiogenesis inhibitor, angiostatin. Cancer Res 56:4887-4890

Giatromanolaki A, Koukourakis MI, Sivridis E, Pastorek J, Wykoff CC, Gatter KC, Harris AL 2001 Expression of hypoxia-inducible carbonic anhydrase-9 relates to angiogenic pathways and independently to poor outcome in non-small cell lung cancer. Cancer Res 61:7992-7998

Gonzalez-Gronow M, Grenert HM, Fuller GM, Pizzo SV 1990 The role of carbohydrate in the function of human plasminogen: comparison of the protein obtained from molecular cloning and expression in E. coli and COS cells. Biochim Biophys Acta 1039:269-274

Gonzalez-Gronow M, Kalfa T, Johnson CE, Gawdi G, Pizzo SV 2003 The voltage-dependent anion channel is a receptor for plasminogen kringle 5 on human endothelial cells. J Biol Chem 278: $27312-27318$

Gordon MS, Margolin K, Talpaz M, Sledge GW, Holmgren E, Benjamin R, Stalter S, Shak S, Adelman D 2001 Phase I safety and pharmacokinetic study of recombinant human antivascular endothelial growth factor in patients with advanced cancer. J Clin Oncol 19:843-850

Grant DS, Kleinman HK 1997 Regulation of capillary formation by laminin and other components of the extracellular matrix. Experientia (suppl)79:317-333

Grant DS, Zukowska Z 2000 Revascularization of ischemic tissues with SIKVAV and neuropeptide Y (NPY). Adv Exper Med Biol 476:139-154

Grant DS, Kleinman HK, Martin GR 1990 The role of basement membranes in vascular development. Ann NY Acad Sci 588:61-72

Grant DS, Kinsella JL, Kibbey MC, LaFlamme S, Burbelo PD, Goldstein AL, Kleinman HK 1995 Matrigel induces thymosin $\beta 4$ gene in differentiating endothelial cells. J Cell Sci 108:3685-3694 
Grinstein S, Woodside M, Waddell TK, Downey GP, Orlowski J, Pouyssegur J, Wong DCP, Foskett JK 1993 Focal localization of the NHE-1 isoform of the $\mathrm{Na}^{+} / \mathrm{H}^{+}$antiport: assessment of effect on intracellular pH. EMBO J 12:5209-5218

Guedez L, Rivera AM, Salloum R, Miller ML, Diegmueller JJ, Bungay PM, Stetler-Stevenson WG 2003 Quantitative assessment of angiogenic responses by the directed in vivo angiogenesis assay. Am J Pathol 162:1431-1439

Gullege CJ, Dewhirst MW 1996 Tumor oxygenation: a matter of supply and demand. Anticancer Res 16:741-749

Gutheil J, Finucane D 2002 Thalidomide therapy in refractory solid tumour patients. Br J Haematol 110:754

Gutheil JC, Campbell TN, Pierce PR, Watkins JD, Huse WD, Bodkin DJ, Cheresh DA 2000 Targeted antiangiogenic therapy for cancer using Vitaxin: a humanized monoclonal antibody to the integrin $\alpha \mathrm{v}-\beta 3$. Clin Cancer Res 6:3056-3061

Hajitou A, Grignet C, Devy L, Berndt S, Blacher S, Deroanne CF, Bajou K, Fong T, Chiang Y, Foidart JM, Noel A 2002 The antitumoral effect of endostatin and angiostatin is associated with a down-regulation of vascular endothelial growth factor expression in tumor cells. FASEB J 16:1802-1804

Hammes HP, Lin J, Renner O, Shani M, Lundqvist A, Betsholtz C, Brownlee M, Deutsch U 2002 Pericytes and the pathogenesis of diabetic retinopathy. Diabetes 51:3107-3112

Hanahan D, Folkman J 1996 Patterns and emerging mechanisms of the angiogenic switch during tumorigenesis. Cell 86:353-364

Heath EI, O'Reilly S, Humphreys R, Sundaresan P, Donehower RC, Sartorius S, Kennedy MJ, Armstrong DK, Carduccim MA, Sorensen JM, Kumor K, Kennedy S, Grochow LB 2001 Phase I trial of the matrix metalloproteinase inhibitor BAY12-9566 in patients with advanced solid tumors. Cancer Chemother Pharmacol 48:269-274

Helmlinger G, Yuan F, Delian M, Jain RK 1997 Interstitial $\mathrm{pH}$ and $\mathrm{pO}_{2}$ gradients in solid tumor in vivo: high-resolution measurements reveal a lack of correlation. Nature Med 3:177-182

Helminger G, Sckell A, Dellian M, Forbes NS, Jain RK 2002 Acid production in glycolysisimpaired tumors provides new insights into tumor metabolism. Clin Cancer Res 8:1284-1291

Herbst RS, Mullani NA, Davis DW, Hess KR, McConkey DJ, Charnsangavej C, O'Reilly MS, Kim HW 2002a Development of biological markers of response and assessment of antiangiogenic activity in a clinical trial of human recombinant endostatin. J Clin Oncol 20:38043814

Herbst RS, Hess KR, Tran HT, Tseng JE, Mullani NA, Charnsangavej C, Madden T, Davis DW 2002b Phase I study of recombinant human endostatin in patients with advanced solid tumors. J Clin Oncol 20:3792-3803

Herbst RS, Maddox AM, Rothenberg ML, Small EJ, Rubin EH, Basela J, Rojo F, Hong WK, Swaisland H, Averbuch SD, Ochs J, LoRusso PM 2002c Selective oral epidermal growth factor receptor tyrosine kinase inhibitor ZD1839 is generally well tolerated and has activity in non-small-cell lung cancer and other solid tumors: results of a phase I trial. J Clin Oncol 20:3815-3825

Hillman N, Cox S, Noble AR, Gallagher PJ 2001 Increased numbers of caveolae in retinal endothelium and pericytes in hypertensive diabetic rats. Eye 15:319-325

Humphries MJ, Oldern K, Yamada KM 1986 A synthetic peptide from fibronectin inhibits experimental metastasis in murine melanoma cells. Science 233:467-470

Jayson GC, Zweit J, Jackson C, Mlulatero C, Julyan P, Ranson M, Broughton I, Wagstaff J, Hakannson L, Groenewegen G, Bailey J, Smith N, Hastings D, Lawrance J, Haroon H, Ward T, McGown AT, Tang M, Levitt D, Marreaud S, Lehmann FF, Herold M, Zwierzina H 2002 Molecular imaging and biological evaluation of HuMV833 anti-VEGF 
antibody: implications for trial design of antiangiogenic antibodies. J Natl Cancer Inst 94:1484-1493

Kaban LB, Mulliken JB, Ezekowitz RA, Ebb D, Smith PS, Folkman J 1999 Antiangiogenic therapy of a recurrent giant cell tumor of the mandible with interferon $\alpha-2 \mathrm{a}$. Pediatrics 103:1145-1149

Kalfa T, Gerritsen M, Carlson E, Binstock A, Tsilibary E 1995 Altered proliferation of retinal microvascular cells on glycated matrix. Invest Ophthalmol Visual Sci 36:2358-2367

Kallinowski F, Vaupel P, Runkel S, Berg G, Fortmeyer HP, Baessler KH, Wagner K, Mueller-Klieser W, Walenta S 1988 Glucose uptake, lactate release, ketone body turnover, metabolic micromilieu, and $\mathrm{pH}$ distributions in human breast cancer xenografts in nude rats. Cancer Res 48:7264-7272

Kaneko T, Konno H, Baba M, Tanaka T, Nakamura S 2003 Urokinase-type plasminogen activator expression correlates with tumor angiogenesis and poor outcome in gastric cancer. Cancer Sci 94: 43-49

Kimura H, Braun RD, Ong ET, Hsu R, Secomb TW, Papahadjopoulos D, Hong K, Dewhirst MW 1996 Fluctuations in red cell flux in tumor microvessels can lead to transient hypoxia and reoxygenation in tumor parenchyma. Cancer Res 56:5522-5528

Knott RM, Robertson M, Muckersie E, Folefac VA, Fairhurst FE, Wileman SM, Forrester JV 1999 A model system for the study of human retinal angiogenesis: activation of monocytes and endothelial cells and the association with the expression of the monocarboxylate transporter type 1 (MCT-1). Diabetologia 42:870-877

Kohn EC, Reed E, Sarosy GA, Minasian L, Bauer KS, Botstick-Bruton F, Kulpha V, Fuse E, Tompkins A, Noone M, Goldspiel B, Pluda J, Figg WD, Liotta LA 2001 A phase I trial of carboxyamido-triazole and paclitaxel for relapsed solid tumors: potential efficacy of the combination and demonstration of pharmacokinetic interaction. Clin Cancer Res 7:1600_1609

Koslowski M, Tureci O, Bell C, Krause P, Lehr HA, Brunner J, Seitz G, Nestle FO, Huber C, Sahin U 2002 Multiple splice variants of lactate dehydrogenase C selectively expressed in human cancer. Cancer Res 62:6750-6755

Koukourakis MI, Giatromanolaki A, Sivridis E, Simopoulos K, Pastorek J, Wykoff CC, Gatter KC, Harris AL 2001 Hypoxia-regulated carbonic anhydrase-9 (CA-9) relates to poor vascularization and resistance of squamous cell head and neck cancer to chemoradiotherapy. Clin Cancer Res 7:3399-3403

Kubota Y, Kleinman HK, Martin GR, Lawley TJ 1988 Role of laminin and basement membrane in the morphological differentiation of human endothelial cells into capillary-like structures. J Cell Biol 107:1589-1598

Lakhani NJ, Sarkar MA, Venitz J, Figg WD 2003 2-Methoxyestradiol, a promising anticancer agent. Pharmacotherapy 23:165-172

Lee EW, Michalkiewicz M, Kitlinska J, Kalezic I, Switalska H, Yoo P, Sangkharat A, Ji H, Li L, Michalkiewicz T, Ljubisavljevic M, Johansson H, Grant DS, Zukowska Z 2003 Neuropeptide $\mathrm{Y}$ induces ischemic angiogenesis and restores function of ischemic skeletal muscles. J Clin Invest 111:1853-1862

Leeper DB, Engin K, Wang JH, Cater JR, Li DJ 1994 Human tumor extracellular pH as a function of blood glucose concentration. Intl J Radiat Oncol Biol Physics 28:935-943

Leeper DB, Engin K, Wang GJ, Li DJ 1998 Effect of i.v. oral glucose on human tumour extracellular $\mathrm{pH}$ for potential sensitization to thermoradiotherapy. Intl $\mathrm{J}$ Hyperthermia 14:257-269

Levitt NC, Eskens FA, O’Byrne KJ, Propper DJ, Denis LJ, Owen SJ, Choi L, Foekens JA, Wilner S, Wood JM, Nakajima M, Talbot DC, Steward WP, Harris AL, Verweij J 2001 
Phase I and pharmacological study of the oral matrix metalloproteinase inhibitors, MM1270 (CGS27023A), in patients with advanced solid cancer. Clin Cancer Res 7:1912-1922

Liu W, Ahmad SA, Reinmuth N, Shaheen RM, Jung YD, Fan F, Ellis LM 2000 Endothelial cell survival and apoptosis in the tumor. Apoptosis 5:323-328

Lockhart AC, Braun RD, Yu D, Ross JR, Dewhirst MW, Humphrey JS, Thompson S, Williams KM, Klitzman B, Yuan F, Grichnik JM, Proia AD, Conway DA, Hurwitz HI 2003 Reduction of wound angiogenesis in patients treated with BMS-275291, a broad spectrum matrix metalloproteinase inhibitor. Clin Cancer Res 9:586-593

Logothetis CJ, Wu KK, Finn LD, Daliani D, Figg W, Ghaddar H, Gutterman JU 2001 Phase I trial of the angiogenesis inhibitor TNP-470 for progressive androgen-independent prostate cancer. Clin Cancer Res 7:1198-1203

Lucas R, Holmgren L, Garcia I, Jimenez B, Mandriota SJ, Borlat F, Sim BK, Wu Z, Grau GE, Shing Y, Soff GA, Bouck N, Pepper MS 1998 Multiple forms of angiostatin induce apoptosis in endothelial cells. Blood 92:4730-4741

Mabjeesh NJ, Escuin D, LaVallee TM, Pribluda VS, Swartz GM, Johnson MS, Willard MT, Zhong H, Simons JW, Giannakakou P 2003 2ME2 inhibits tumor growth and angiogenesis by disrupting microtubules and dysregulating HIF. Cancer Cell 3:363-375

Macchiarini P, Fontanini G, Hardin MJ, Squartini F, Angeletti CA 1992 Relation of neovascularisation to metastasis of non-small-cell lung cancer. Lancet 340:145-146

Matsunaga T, Weihrauch DW, Moniz MC, Tessmer J, Warltier DC, Chilian WM 2002 Angiostatin inhibits coronary angiogenesis during impaired production of nitric oxide. Circulation 105:2185-2191

Mauceri HJ, Hanna NN, Beckett MA, Gorski DH, Staba MJ, Stellato KA, Bigelow K, Heimann R, Gately S, Dhanabal M, Soff GA, Sukhatme VP, Kufe DW, Weichselbaum RR 1998 Combined effects of angiostatin and ionizing radiation in antitumour therapy. Nature Rev Cancer 394:287-291

McDonald DM, Baluk P 2002 Significance of blood vessel leakiness in cancer. Cancer Res 62:5381-5385

McSwine RL, Babnigg G, Musch MW, Change EB, Villereal ML 1994 Expression and phosphorylation of NHE1 in wild-type and transformed human and rodent fibroblasts. J Cell Physiol 161:351-357

Moser TL, Stack MS, Asplin I, Enghild JJ, Hojrup P, Everitt L, Hubchak S, Schnaper HW, Pizzo SV 1999 Angiostatin binds ATP synthase on the surface of human endothelial cells. Proc Natl Acad Sci USA 96:2811-2816

Moser TL, Kenan DJ, Ashley TA, Roy JA, Goodman MD, Misro UK, Cheek DJ, Pizzo S 2001 Endothelial cell surface F1-Fo ATP synthase is active in ATP synthesis and is inhibited by angiostatin. Proc Natl Acad Sci USA 98:6656-6661

Mundhenke C, Thomas JP, Wilding G, Lee FT, Kelzc F, Chappell R, Neider R, Sebree LA, Friedl A 2001 Tissue examination to monitor antiangiogenic therapy: a phase I clinical trial with endostatin. Clin Cancer Res 7:3366-3374

Muthukkaruppan VR, Auerback R 1970 Angiogenesis in the mouse cornea. Science 205:14161418

Newell K, Franchi A, Pouyssegur J, Tannock IF 1993 Studies with glycolysis-deficient cells suggest that production of lactic acid is not the only cause of tumor acidity. Proc Natl Acad Sci USA 90:1127-1131

Nicosia RF, Ottinetti A 1990 Growth of microvessels in serum-free matrix culture of rat aorta. Lab Invest 63:115-122

Nicosia RF, Tuszynski GP 1994 Matrix-bound thrombospondin promotes angiogenesis in vitro. J Cell Biol 124:183-193 
Nicosia RF, Nicosia SV, Smith M 1994 Vascular endothelial growth factor, platelet-derived growth factor, and insulin-like growth factor-1 promote rat aortic angiogenesis in vitro. Am J Pathol 145:1023-1029

Noma H, Funatsu H, Yamashita H, Kitano S, Mishima HK, Hori S 2002 Regulation of angiogenesis in diabetic retinopathy: possible balance between vascular endothelial growth factor and endostatin. Arch Ophthalmol 120:1075-1080

Oates PJ 2002 Polyol pathway and diabetic peripheral neuropathy. Intl Rev Neurobiol. 50:325-392

Olive PL, Aquino-Parsons C, MacPhail SH, Liao SY, Raleigh JA, Lerman MI, Stanbridge EJ 2001 Carbonic anhydrase 9 as an endogenous marker for hypoxic cell in cervical cancer. Cancer Res 61:8924-8929

O'Reilly MS, Holmgren L, Shing Y, Chen C, Rosenthal RA, Moses M, Lane WS, Cao Y, Sage EH, Folkman J 1994a Angiostatin: a novel angiogenesis inhibitor that mediates the suppression of metastases by a Lewis lung carcinoma. Cell 79:315-328

O'Reilly MS, Holmgren L, Shing Y, Chen C, Rosenthal RA, Cao Y, Moses M, Lane WS, Sage EH, Folkman J 1994b Angiostatin: a circulating endothelial cell inhibitor that suppresses angiogenesis and tumor growth. Cold Spring Harbor Symp Quant Biol 59:471-482

O'Reilly MS, Boehm T, Shing Y, Fukai N, Vasios G, Lane WS, Flynn E, Birkhead JR, Olsen BR, Folkman J 1997 Endostatin: an endogenous inhibitor of angiogenesis and tumor growth. Cell Physiol Biochem 88:277-285

OSI Pharmaceuticals, Genentech, Roche 2001 OSI Pharmaceuticals, Genentech and Roche announce data from clinical studies of Tarceva. Expert Rev Anticancer Ther 1:4-5

Ossowski L, Reich E 1983 Antibodies to plasminogen activator inhibit tumor metastasis. Cell 88:611-619

Owen CS, Pooler PM, Wahl ML, Bobyock SB, Coss RA, Leeper DB 1997 Altered proton extrusion in cells adapted to growth at low extracellular pH. J Cell Physiol 173:397-405

Planus E, Barlovatz-Meimon G, Rogers RA, Bonavaud S, Ingber DE, Wang N 1997 Binding of urokinase to plasminogen activator inhibitor type-1 mediates cell adhesion and spreading. J Cell Sci 110:1091-1098

Posey JA, Ng TC, Yang B, Khazaeli MB, Carpenter MD, Fox F, Needle M, Waksal H, LoBuglio AF 2003 A phase I study of anti-kinase insert domain-containing receptor antibody, IMC1C11, in patients with liver metastases from colorectal carcinoma. Clin Cancer Res 9:13231332

Ranson M, Hammond LA, Ferry D, Kris M, Tullo A, Murray PI, Miller V, Averbuch S, Ochs J, Morris C, Feyereislova A, Swaisland H, Rowinsky EK 2002 ZD1839, a selective oral epidermal growth factor receptor-tyrosine kinase inhibitor, is well tolerated and active in patients with solid, malignant tumors: results of a phase I trial. J Clin Oncol 20:2240-2250

Reber F, Gersch U, Funk RW 2003 Blockers of carbonic anhydrase can cause increase of retinal capillary diameter, decrease of extracellular and increase of intracellular $\mathrm{pH}$ in rat retinal organ culture. Graefes Arch Clin Exp Ophthalmol 241:140-148

Redman BG, Esper P, Pan Q, Dunn RL, Hussain HK, Chenevert T, Brewer GJ, Merajver SD 2003 Phase II trial of tetrathiomolybdate in patients with advanced kidney cancer. Clin Cancer Res 9:1666-1672

Reimer CL, Agata N, Tammam JG, Bamberg M, Dickerson WM, Kamphaus GD, Rook SL, Milhollen M, Fram R, Kalluri R, Kufe D, Kharbanda S 2002 Antineoplastic effects of chemotherapeutic agents are potentiated by NM-3, an inhibitor of angiogenesis. Cancer Res 62:789-795

Ries M, Basseau F, Tyndal B, Jones R, Deminiere C, Catargi B, Combe C, Moonen CW, Grenier N 2003 Renal diffusion and BOLD MRI in experimental diabetic nephropathy. J Magnet Reson Imag 17:104-113 
Risau W, Lemmon V 1988 Changes in the vascular extracellular matrix during embryonic vasculogenesis and angiogenesis. Dev Biol 125:441-450

Robert F, Ezekiel MP, Spencer SA, Meredith RF, Bonner JA, Khazaeli MB, Saleh MN, Carey D, LoBuglio AF, Wheeler RH, Cooper MR, Waksal HW 2001 Phase I study of antiepidermal growth factor receptor antibody cetuximab in combination with radiation therapy in patients with advanced head and neck cancer. J Clin Oncol 19:3234-3243

Roskelley CD, Bissell MJ 2002 The dominance of the microenvironment in breast and ovarian cancer. Semin Cancer Biol 12:97-104

Rudek MA, Figg WD, Dyer V, Dahut W, Turner ML, Steinberg SM, Liewehr DJ, Kohler DR, Pluda JM, Reed E 2001 Phase I clinical trial of oral COL-3, a matrix metalloproteinase inhibitor, in patients with refractory metastatic cancer. J Clin Oncol 19:584-592

Sandberg JA, Parker VP, Blanchard KS, Sweedler D, Powell JA, Kachensky A, Bellon L, Usman N, Rossing T, Borden E, Blatt LM 2000 Pharmacokinetics and tolerability of an antiangiogenic ribozyme (ANGIOZYME) in healthy volunteers. J Clin Pharmacol 40:1462_ 1469

Schober T, Bilzer T, Waha A, Reifenberger G, Wechsler W, Dieimling A, Wiestler OD, Westphal M, Kemshead JT, Vega F 1995 The epidermal growth factor receptor in glioblastoma: genomic amplification, protein expression, and patient survival data in a therapeutic trial. Clin Neuropathol 14:169-174

Schwartz MA, Lechene C, Ingber DE 1991a Insoluble fibronectin activates the $\mathrm{Na}^{+} / \mathrm{H}^{+}$antiporter by clustering and immobilizing integrin $\alpha_{\mathrm{v}} \beta 1$, independent of cell shape. Proc Natl Acad Sci USA 88:7849-7853

Schwartz MA, Ingber DE, Lawrence M, Springer TA, Lechene C 1991b Multiple integrins share the ability to induce elevation of intracellular pH. Exp Cell Res 195:533-535

Secomb TW, Hsu R, Dewhirst MW, Klitzman B, Gross JF 1993 Analysis of oxygen transport to tumor tissue by microvascular networks. Intl J Radiat Oncol Biol Phys 25:481-489

Sennlaub F, Valamanesh F, Vazquez-Tello A, El-Asrar AM, Checchin D, Brault S, Gobeil F, Beauchamp MH, Mwaikambo B, Courtois Y, Geboes K, Varma DR, Lachapelle P, Ong H, Behar-Cohen F, Chemtob S 2003 Cyclooxygenase-2 in human and experimental ischemic proliferative retinopathy. Circulation 108:198-204

Shan S, Sorg B, Dewhirst MW 2003 A novel rodent mammary window of orthotopic breast cancer for intravital microscopy. Microvasc Res 65:109-117

Shepherd FA, Giaccone G, Seymour L, Debruyne C, Bezjak A, Hirsh V, Smylie M, Rubin S 2002 Prospective, randomized, double-blind, placebo-controlled trial of marimastat after response to first-line chemotherapy in patients with small-cell lung cancer: a trial of the National Cancer Institute of Canada-Clinical Trials Group and the European Organization for Research and Treatment of Cancer. J Clin Oncol 20:4434-4439

Short SC, Traish D, Dowe A, Hines F, Gore M, Brada M 2001 Thalidomide as an anti-angiogenic agent in relapsed gliomas. J Neurooncol 51:41-45

Soff GA, Hong J, Fishman D, Schultz R, Cundiff DL, Park S, Enghild JJ, Stack MS, Gately S 1999 Angiostatin 4.5: a naturally occurring human angiogenesis inhibitor. Proc Am Assoc Cancer Res 40:4088

Sood AK, Gupta B, Chugh P 1999 Topical amiloride accelerates healing and delays neovascularization in mechanically produced corneal ulcers in rabbits. Meth Findings Exp Clin Pharmacol 21:491-497

Spranger J, Hammes HP, Preissner KT, Schatz H, Pfeiffer AF 2000 Release of the angiogenesis inhibitor angiostatin in patients with proliferative diabetic retinopathy: association with retinal photocoagulation. Diabetologia 43:1404-1407 
Stopeck AM, Sheldon M, Vahedian G, Cropp R, Gosalia R, Hannah A 2002 Results of a phase I dose-escalating study of the antiangiogenic agent, SU5416, in patients with advanced malignancies. Clin Cancer Res 8:2798-2805

Sudhakar A, Sugimoto H, Yang C, Lively J, Zeisberg M, Kalluri R 2003 Human tumstatin and human endostatin exhibit distinct antiangiogenic activities mediated by alpha $\mathrm{v}$ beta 3 and alpha 5 beta 1 integrins. Proc Natl Acad Sci USA 100:4766-4771

Swinson DE, Jones JL, Richardson D, Wykoff CC, Turley H, Pastorek J, Taub N, Harris AL, O'Byrne KJ 2003 Carbonic anhydrase IX expression, a novel surrogate marker of tumor hypoxia, is associated with poor prognosis in non-small cell lung cancer. J Clin Oncol 21:473-482

Tarui T, Miles LA, Takada Y 2001 Specific interaction of angiostatin with integrin $\alpha_{\mathrm{v}} \beta_{3}$ in endothelial cells. J Biol Chem 276:39562-29567

te Velde EA, Vogten JM, Gebbink MF, van Gorp JM, Voest EE, Borel RI 2002 Enhanced antitumour efficacy by combining conventional chemotherapy with angiostatin or endostatin in a liver metastasis model. Br J Surg 89:1302-1309

Thews O, Kelleher DK, Esser N, Kraus S, Vaupel P 2003 Lack of association between tumor hypoxia, GLUT-1 expression and glucose uptake in experimental sarcomas. Adv Exp Med Biol 510:57-61

Thistlethwaite AJ, Alexander GA, Moylan DJ, Leeper DB 1987 Modification of human tumor pH by elevation of blood glucose. Intl J Radiat Oncol Biol Physics 13:603-610

Thomas JP, Arzoomanian RZ, Alberti D, Marnocha R, Lee F, Friedl A, Tutsch K, Dresen A 2003 Phase I pharmacokinetic and pharmacodynamic study of recombinant human endostatin in patients with advanced solid tumors. J Clin Oncol 21:223-231

Troyanovsky B, Levchenko T, Mansson G, Matvijenko O, Holmgren L 2001 Angiomotin: an angiostatin binding protein that regulates endothelial cell migration and tube formation. J Cell Biol 152:1247-1254

Tulpule A, Scadden DT, Espina BM, Cabriales S, Howard W, Shea K, Gill PS 2000 Results of a randomized study of IM862 nasal solution in the treatment of AIDS-related Kaposi's sarcoma. J Clin Oncol 18:716-723

Turetschek K, Preda A, Floyd E, Shames DM, Novikov V, Roberts TP, Wood JM, Fu Y, Carter WO, Brasch RC 2002 MRI monitoring of tumor response to a novel VEGF tyrosine kinase inhibitor in an experimental breast cancer model. Acad Radiol 9(suppl 2):S519-S520

van Hinsbergh VW, Collen A, Koolwijk P 2001 Role of fibrin matrix in angiogenesis. Ann NY Acad Sci 936:426-437

Vassalli J-D, Appino A-P, Belin D 1991 The plasminogen activator/plasmin system. J Clin Invest 88:1067-1072

Vaupel P 1997 Blood flow and oxygenation status of head and neck carcinomas. Adv Exp Med Biol 428:89-95

Vaupel P, Kallinowski F, Okunieff P 1989 Blood flow, oxygen and nutrient supply, and metabolic microenvironment of human tumors: a review. Cancer Res 49:6449-6465

Vaupel P, Thews O, Kelleher DK, Hoeckel M 1998 Current status of knowledge and critical issues in tumor oxygenation. Results from 25 years research in tumor pathophysiology. Adv Exp Med Biol 454:591-602

Verstappen CC, Postma TJ, Hoekman K, Heimans JJ 2003 Peripheral neuropathy due to therapy with paclitaxel, gemcitabine, and cisplatin in patients with advanced ovarian cancer. J Neurooncol 63:201-205

Wachsberger PR, Gressen EL, Bhala A, Bobyock SB, Storck C, Coss RA, Berd D, Leeper DB 2002 Variability in glucose transporter 1 levels and hexokinase activity in human melanoma. Melanoma Res 12:35-43 
Wahl ML, Grant DS 2002 Effects of microenvironmental extracellular $\mathrm{pH}$ and extracellular matrix proteins on angiostatin's activity and on intracellular pH. J Gen Pharm (Vascular) 35:1-10

Wahl ML, Coss RA, Bobyock SB, Leeper DB, Owen CS 1996 Thermotolerance and intracellular $\mathrm{pH}$ in two Chinese hamster cell lines adapted to growth at low pH. J Cell Physiol 166:438-445

Wahl ML, Page AR, Tootell M, Zahaczewsky M, Owen CS, Grant DS 2001 Low extracellular pH promotes the anti-angiogenic response of endothelial cells to rh-angiostatin. In: Proceedings of the $92^{\text {nd }}$ Annual Meeting of the American Association for Cancer Research. New Orleans, abstract 27, p 5

Wahl ML, Owen CS, Grant DS 2002a Low dose angiostatin induces intracellular acidosis and anoikis cell death in endothelial cells at tumor-like low pH. Endothelium 9:205-216

Wahl ML, Owen JA, Burd R, Herlands RA, Nogami SS, Rodeck U, Berd D, Leeper DB, Owen CS 2002b Regulation of intracellular pH in human melanoma: potential therapeutic implications. Mol Cancer Ther 1:617-628

Walenta S, Salameh A, Lyng H, Evensen JF, Mitze M, Rofstad EK, Mueller-Klieser W 1997 Correlation of high lactate levels in head and neck tumors with incidence of metastasis. Am J Pathol 150:409-415

Walter JJ, Sane DC 1999 Angiostatin binds to smooth muscle cells in the coronary artery and inhibits smooth muscle cell proliferation and migration in vitro. Arterioscler Thromb Vasc Biol 19:2041-2048

Weidner N, Semple JP, Welch WR, Folkman J 1991 Tumor angiogenesis and metastasiscorrelation in invasive breast carcinoma. N Engl J Med 324:1-8

Weidner N, Carroll PR, Flax J, Blumenfeld W, Folkman J 1993 Tumor angiogenesis correlates with metastasis in invasive prostate carcinoma. Am J Pathol 143:410-409

Whatmore JL, Swann E, Barraja P, Newsome JJ, Bunderson M, Beall HD, Tooke JE, Moody CJ 2002 Comparative study of isoflavone, quinoxaline and oxindole families of antiangiogenic agents. Angiogenesis 5:45-51

White RR, Shan S, Rusconi CP, Shetty G, Dewhirst MW, Kontos CD, Sullenger B 2003 Inhibition of rat corneal angiogenesis by a nuclease-resistant RNA aptamer specific for angiopoietin-2. Proc Natl Acad Sci USA 100:5028-5033

Yamagata M, Tannock IF 1996 The chronic administration of drugs that inhibit the regulation of intracellular $\mathrm{pH}$ : in vitro and anti-tumour effects. Br J Cancer 73:1328-1334

Yegutikin GG, Henttinen T, Samburski SS, Spychala J, Jalkanen S 2002 The evidence for two opposite, ATP-generating and ATP-consuming, extracellular pathways on endothelial and lymphoid cells. Biochem J 367:121-128

Yokoyama Y, Dhanabal M, Griffioen AW, Sukhatme VP, Ramakrishnan S 2000 Synergy between angiostatin and endostatin: inhibition of ovarian cancer growth. Cancer Res 60: 2190-2196

Zhang L, Yang N, Park JW, Katsaros D, Fracchioli S, Cao G, O'Brien-Jenkins A, Randall TC, Rubin SC, Coukos G 2003 Tumor-derived vascular endothelial growth factor up-regulates angiopoietin-2 in host endothelium and destabilizes host vasculature, supporting angiogenesis in ovarian cancer. Cancer Res 63:3403-3412 